\title{
CHOICE OF MAJORS: \\ ARE WOMEN REALLY DIFFERENT FROM MEN?
}

\author{
Adriana D. Kugler \\ Catherine H. Tinsley \\ Olga Ukhaneva \\ Working Paper 23735 \\ http://www.nber.org/papers/w23735 \\ NATIONAL BUREAU OF ECONOMIC RESEARCH \\ 1050 Massachusetts Avenue \\ Cambridge, MA 02138 \\ August 2017
}

We are grateful to George Akerlof, David Autor, Kirsten Butcher, David Figlio, Nicole Fortin, Donna Ginther, Claudia Goldin, Harry Holzer, Lisa Kahn, Shulamit Kahn, Victor Lavy, John Mayo, Bruce Sacerdote, and participants at the Harvard Business School's Negotiation, Organizations and Market's speaker series for comments. We also thank the staff at the University's registrar's office and career center for help with the data collection. The views expressed herein are those of the authors and do not necessarily reflect the views of the National Bureau of Economic Research.

NBER working papers are circulated for discussion and comment purposes. They have not been peer-reviewed or been subject to the review by the NBER Board of Directors that accompanies official NBER publications.

(C) 2017 by Adriana D. Kugler, Catherine H. Tinsley, and Olga Ukhaneva. All rights reserved. Short sections of text, not to exceed two paragraphs, may be quoted without explicit permission provided that full credit, including $\odot$ notice, is given to the source. 
Choice of Majors: Are Women Really Different from Men?

Adriana D. Kugler, Catherine H. Tinsley, and Olga Ukhaneva

NBER Working Paper No. 23735

August 2017

JEL No. I23,I24,I26,J16

\begin{abstract}
Recent work suggests that women are more responsive to negative feedback than men in certain environments. We examine whether negative feedback in the form of relatively low grades in major-related classes explains gender differences in the final majors undergraduates choose. We use unique administrative data from a large private university on the East Coast from 2009-2016 to test whether women are more sensitive to grades than men, and whether the gender composition of major-related classes affects major changes. We also control for other factors that may affect a student's final major including: high school student performance, gender of faculty, and economic returns of majors. Finally, we examine how students' decisions are affected by external cues that signal STEM fields as masculine. The results show that high school academic preparation, faculty gender composition, and major returns have little effect on major switching behaviors, and that women and men are equally likely to change their major in response to poor grades in major-related courses. Moreover, women in male-dominated majors do not exhibit different patterns of switching behaviors relative to their male colleagues. Women are, however, more likely to switch out of male-dominated STEM majors in response to poor performance compared to men. Therefore, we find that it takes multiple signals of lack of fit into a major (low grades, gender composition of class, and external stereotyping signals) to impel female students to switch majors.
\end{abstract}

Adriana D. Kugler

Georgetown University

McCourt School of Public Policy

37th and O Streets NW, Suite 311

Washington, DC 20057

and NBER

ak659@georgetown.edu

Catherine H. Tinsley

Georgetown University

tinsleyc@georgetown.edu
Olga Ukhaneva

Georgetown University

oru@georgetown.edu 


\section{Introduction}

Numerous studies have documented differences in earnings across college majors (e.g., Grogger and Eide (1995)). Women predominantly choose majors that lead to lower paid occupations such as humanities, education, and some of the social sciences, such as psychology, while men choose majors that lead to higher-paying jobs such as science, engineering, and business. Thus, despite a steady increase in the share of women's college enrollments (Goldin et al. (2006)), the gender gap in wages persists. Hence, understanding why women and men graduate with different majors is critical for understanding later occupational opportunities and other choices that can influence the gender wage gap.

A growing literature suggests that women are more sensitive to negative feedback than men (Roberts (1991); Johnson and Helgeson (2002); Mayo et al. (2012)). We examine whether women are more likely than men to opt out of a major in response to low grades. Twelve percent of students in our data change majors at least once, and $60 \%$ of those who switch are women, so that the gender concentration of any major is determined not only by students' initial choice but also by their major switching behavior during college. Because changing one's major bears a higher cost compared to initial choice, factors that affect the initial major choice might be different from the factors that influence student's persistence in a major.

To motivate the empirical analysis, we adapt Oxoby's (2014) model of occupational choice to the problem of major choice. In this model, a student's decision to persist in a major is influenced by an imperfect signal about own abilities (grades in major-related classes), and internalized signals about "fit" (gender composition of major-related classes and signals from the broader social environment about gender fit). As students assess their fit, they can

develop biases that drive either an overestimation or underestimation of their likelihood of success. Oxoby's model is primarily concerned with observable demographics that agents use to assess fit. For our purposes, the model, thus, implies that if a male student sees many other male history majors, he might overestimate his likelihood of graduating successfully as 
a history major, even with low grades. We extend his model to assess how the oft-repeated association between males and STEM fields creates an additional signal about the masculine nature of STEM fields.

STEM fields continue to be stereotyped as masculine (Francis et al. (2017)), even though measured levels of a student's masculinity do not predict performance (at least not in mathematics (Hackett (1985))). Thus, while men may not have a natural ability advantage in STEM fields, the numerous government and other policy initiatives designed to get women interested in STEM fields may have the unintended effect of signaling to women an inherent lack of fit. Initiatives designed to overcome the masculine STEM stereotype might send subtle signals to women that lead them to underestimate their success and increase their likelihood of switching out in response to low grades, relative to men.

To test empirically the predictions of the theoretical model, we use a comprehensive dataset from a large private university on the East Coast. Our data contain information on every student who attended the university during 2009-2016, including the information about students' major in every term, classes attended, their final grades, and class and faculty composition in each course. We are able to track students' decisions over time, including current and alternative majors (majors that students switch into) and construct relative measures that compare students' realized outcomes in current and alternative majors. We, then, use these relative measures to identify factors that influence students' decisions to change majors.

We find that, in line with the model's predictions, both women and men are more likely to change majors in response to poor grades in major-related courses. However, contrary to the model's predictions, we do not find that women are more likely to switch out of either female- or male-dominated majors because of low grades compared to their male colleagues, except when we isolate STEM majors. Women in male-dominated STEM majors, according to our results, are more likely to change major compared to men when their grades in majorrelated courses are low. Therefore, we find that it takes multiple cues signaling lack of fit 
with a major (low grades, gender composition of class, and external stereotyping signals) to impel students to switch majors.

In addition, we find that pre-college preparation does not affect the decision to change major and neither does the composition of faculty in terms of gender or race. Finally, we find that returns to a field affect major choices more during downturns, but these are equally important for both men and women.

Our study contributes to the growing literature that treats choice of major as a dynamic, rather than a static, process during which students learn about major attributes and their abilities in it. Our study is closest to those of Ost (2010), Stinebrickner and Stinebrickner (2013), and Astorne-Figari and Speer (2017) that examine switches across majors. Ost (2010), like us, uses administrative data to examine persistence in a major, though his data only include physical and life sciences. As our model would predict, he finds that as students' GPA increases, the likelihood of major switches decreases. He also finds that females are more responsive to grades than their male colleagues, but only in physical sciences.

Stinebrickner and Stinebrickner (2013) also rely on administrative data on students' majors and grades as well as survey data on students' expectations about their major at graduation. The authors find that, at the start of their freshman year, students are overly optimistic about their abilities to do well in sciences and the only way to update these beliefs is to actually take science classes.

Astorne-Figari and Speer (2017) study factors that impact the decision to change majors using nationwide survey data of the U.S. population. They find that students switch out of majors when they can improve their grades, and that the lower the grades are, the greater the switch a student might make in terms of dissimilarity of academic requirements. Thus, consistent with the model we present, the lower the grades, the lower the ability the student infers about himself or herself and the larger the cost he/she is willing to bear to make a switch. Also, they find that students switch into majors that 'look' like them in terms of 
gender and race, and that female gender is a large driver of switches out of STEM majors. ${ }^{1}$

We complement the literature of major switches by, first, using a unique dataset that allows us to incorporate a multitude of factors used in existing studies in a single empirical model. Therefore, we are able to disentangle the impacts of signals about abilities (grades) and signals about fit (e.g., demographic minority and the stereotype of STEM fields as masculine) from the impacts of pre-college preparation, returns to a major, and role models. Second, we are able to take advantage of a very granular data that tracks each student's progress in college over time instead of relying on aggregate data.

Existing studies have primarily focused on four factors that influence students' decisionmaking: (1) grades (see studies by Long (1986); Jensen and Owen (2000); Arcidiacono et al. (2012); Zafar (2013); Wiswall and Zafar (2014); and Kirkeboen et al. (2016)); (2) pre-college preparation (see studies by Altonji (1995); Turner and Bowen (1999); Morgan et al. (2013); Griffith (2010); Levine and Zimmerman (1995); and Speer (2017)); (3) returns to major and workplace preferences (see studies by Arcidiacono (2004); Arcidiacono et al. (2012); Bradley (2012); Gemici and Wiswall (2014); Zafar, 2015; Blom et al. (2015); Bronson (2014); and Kirkeboen et al. (2016)); and (4) class and faculty composition (Canes and Rosen (1995); Dynan and Rouse (1997); Bettinger and Long (2005); Carrell et al. (2010); and Feld and Zölitz (2017)). We include all the factors listed above in our model as they are important to any analysis of major choice.

The rest of the paper is organized as follows. Section 2 describes the theoretical framework. Section 3 describes our data. Section 4 presents our identification strategy. Section 5 describes the results, and Section 6 concludes.

\footnotetext{
${ }^{1}$ Like our paper, the Astorne-Figari and Speer (2017) paper conducts a comprehensive analysis of a multitude of factors affecting major switches. However, the measures included in their paper to control for the key factors of interest are problematic in a number of ways. First, the GPA data they have is not linked to specific courses or subjects, so they cannot identify student's performance in his or her major. Second, the data on gender and race in majors comes from the American Community Survey and is not specific to the college or courses students attend but rather include the national average composition of gender and race in majors across the country.
} 


\section{Model}

In this section, we outline a model developed by Oxoby (2014) that ties together exogenous signals about fit with individuals' beliefs about their own abilities. This model describes how agents incorporate information from the environment about their fitness in a field and how that is used to update their beliefs about their own abilities and expected success. In the model there are two types of agents and two types of occupations (majors). The two "types" of agents are those who fit and those who do not fit. These types, denoted by $j=\{1,2\}$, are observable and hence are known to everyone; $m_{j}$ represents the fraction of the population of type $j$, and $m_{1}+m_{2}=1$.

Innate ability is denoted by $a=\{H, L\}$, where $H$ stands for high ability, and $L$ stands for low ability. In our context, ability reflects the probability of successfully graduating in a certain major. Agents are uncertain about their own abilities. They form a belief about their abilities based on a private and imperfect signal $\theta \in[0,1]$ (i.e., grades). We assume that for agents of type $a$, signal $\theta$ is distributed according to $F_{a}(\theta)$, with density $f_{a}(\theta)$. We assume that higher $\theta$ indicates that an agent is more likely to be high rather than low ability, i.e., $F_{H}(\theta)<F_{L}(\theta)$. We also, assume that distributions $F_{H}(\theta)$ and $F_{L}(\theta)$ are independent of observable types (i.e., abilities do not depend on gender, race, etc). We assume that initially

agents believe that they are equally able, i.e., $F_{H}(\theta \mid t)=F_{L}(\theta \mid t)=\frac{1}{2}$ for $j \in\{1,2\}$ and $a \in\{H, L\}$.

In the absence of any biases, agents update their beliefs according to Bayes' rule. The agent estimates that the probability of being type $a=H$ upon receiving the signal $\theta$ is given by:

$$
p(\theta)=\frac{f_{H}(\theta)}{f_{H}(\theta)+f_{L}(\theta)}
$$




\section{$2.1 \quad$ Biases}

Following Oxoby (2014) who builds on the work of Manski (1993) and Chung (2000) among others, we assume that individuals may incorporate information about observable types into their beliefs about own ability. For example, individuals might use information about distribution of types (i.e., gender, race, etc.) across majors to estimate their own abilities in a certain major. For example, a female student might feel less confident about doing well in Economics if she observes that the share of females in Economics classes, the number of females graduating with Economics major, or the number of female professors teaching Economics classes, is very small. The phenomenon, when an individual's subjective beliefs about her abilities based on a signal $\theta$ and observed characteristics of a major differs from objective beliefs about her abilities based only on signal $\theta$ is called a type-based bias.

To formalize this phenomenon, we utilize a model in which a student enters a university and in each term observes class and faculty composition of various classes related to majors, as well as receives signals about their ability in the form of grades. We assume that there are two types of majors - more prestigious and less prestigious (in terms of job opportunities and payoffs). ${ }^{2}$ Let $\mu_{j}$ be the fraction of agents of type $j$ in a more prestigious major (more prestigious major also implies higher costs/efforts to fulfill its requirements). For example, it may represent a fraction of men in STEM majors. Then, a type-based bias can we expressed as a function $\beta_{t}=\beta\left(\mu_{t}, \mu_{-t}\right):[0,1]^{2} \rightarrow[0,1]$. The function $\beta(\cdot)$ is assumed to be increasing in $\mu_{j}$, decreasing in $\mu_{-j}$ and $\beta\left(\mu_{j}, \mu_{-j}\right)=\frac{1}{2}$. That is if, for example, there are more individuals of type 1 in the more prestigious major, then individual's of type 1 bias is $\beta_{1}=\beta\left(\mu_{1}, \mu_{2}\right)>\frac{1}{2}$.

When an individual's decision-making is affected by a social structure (distribution of types across majors), i.e., type-based bias is present, an individual's belief that she's high ablilty $(a=H)$ given a private signal $\theta$ and observations $\mu_{1}$ and $\mu_{2}$ is updated in the following

\footnotetext{
${ }^{2} \mathrm{~A}$ natural extension of this framework would be a model with multiple types and majors, however, for the purposes of our analysis this simple two majors model nicely demonstrates mechanisms underlying individual's decision-making.
} 
way:

$$
p_{j}(\theta)=\frac{f_{H}(\theta) \beta_{j}}{f_{H}(\theta) \beta_{j}+f_{L}(\theta)\left(1-\beta_{j}\right)},
$$

we will call this belief subjective as it is influenced by 'irrelevant' information, i.e., distribution of types. ${ }^{3}$

The bias influences student's beliefs in the following way: (1) when $\mu_{j}=\mu_{-j}, \beta_{j}=\frac{1}{2}$ and subjective beliefs coincide with objective beliefs, i.e., $p_{j}(\theta)=p(\theta)$; $(2)$ when $\mu_{j}>\mu_{-j}$, type $j$ individual is overconfident about her ability, i.e., $p_{j}(\theta)>p(\theta)$; (3) when $\mu_{j}<\mu_{-j}$, type $j$ individual is under-confident about her ability, i.e., $p_{j}(\theta)<p(\theta)$. Therefore, the probability of success is increasing in $\beta$. In other words, when a student observes that her type is overrepresented in a certain major, she overestimates her probability of success; when, on the opposite, a student's type is underrepresented in a certain major, she under-estimates her probability of success in that major.

\subsection{Biases and the Choice of Major}

Next, we analyze how the type-based biases impact individual's choice of major. Any student who graduates with a less prestigious major receives payoff $\bar{V}>0$ irrelevant of her abilities. Payoffs in a more prestigious major, in contrast, depend on a student's ability: an able student receives payoff $V_{H}>\bar{V}$, however, less able student receives payoff $V_{L}<\bar{V}$. For example, a student who is less able might not be able to graduate in a major that requires more effort, or even if they graduate with a harder major their payoff might be much lower due to a low GPA and therefore fewer lucrative job opportunities. Therefore, able students are better off graduating in more prestigious majors, whereas less able students are better off graduating in less prestigious majors. This separating equilibrium is Pareto efficient.

\footnotetext{
${ }^{3}$ Tversky and Kahneman (1975) demonstrate that irrelevant information might indeed impact one's judgement.
} 
In the absence of biases, students choose more prestigious major when

$$
p(\theta) V_{H}+(1-p(\theta)) V_{L} \geq \bar{V}
$$

or

$$
p(\theta) \geq \frac{\bar{V}-V_{L}}{V_{H}-V_{L}} .
$$

Therefore, there exists a threshold $\tilde{\theta}$ that solves

$$
p(\tilde{\theta})=\frac{\bar{V}-V_{L}}{V_{H}-V_{L}} .
$$

Students that receive private signal $\theta \geq \tilde{\theta}$ will choose the more prestigious major, whereas students that receive a signal $\theta<\tilde{\theta}$ will choose the less prestigious major.

With a type-based bias, this threshold changes because now the probability of being high ability is impacted by bias given in equation (2). Without loss of generality, assume that $\mu_{1}>\mu_{2}$, meaning that a more prestigious major has a higher share of type 1 students. Therefore, $\beta\left(\mu_{1}, \mu_{2}\right)>\frac{1}{2}$, and therefore because $p_{1}\left(\tilde{\theta}_{1}\right)=p(\tilde{\theta})=p_{2}\left(\tilde{\theta}_{2}\right)$ and $p_{j}(\theta)$ increases in $\beta, \tilde{\theta}_{1}<\tilde{\theta}<\tilde{\theta}_{2}$. That means that in the presence of biases, some students of type 1 who are not sufficiently skilled, but whose type is overrepresented in a more prestigious major, will choose a more prestigious major - when $\theta \in\left(\tilde{\theta}_{1}, \tilde{\theta}\right]$. And some students of type 2 who are sufficiently skilled, but whose type underrepresented in a more prestigious major, will opt out into a less prestigious major - when $\theta \in\left(\tilde{\theta}, \tilde{\theta}_{2}\right]$. Therefore, this model predicts that some students will be matched to majors in an inefficient way.

Based on the model, we test the following hypotheses:

- Students will gravitate to majors in which they receive better grades.

- Demographically imbalanced majors will encourage those in the majority to overestimate their abilities (males in male-dominated majors and females in female-dominated 
majors) and persist, even when they perform poorly.

- The stereotypical association of STEM as masculine fields will also contribute to typebased bias encouraging females to underestimate their abilities in these majors, relative to men.

\section{Data Description}

The data for this project were collected at a large private university on the East Coast (hereafter referred to as 'University'). The data recorded by the University's registrar, admissions, and financial aid offices were anonymized and provided to us for this research. The data are collected from all four schools within the University - the college, the business school, the school of international relations, and the school of health studies.

For each student, we have information on whether a student is registered for classes in each term during the period of enrollment as well as student's first and second majors (if either is chosen) in each term. Our dependent variable Switch is an indicator that takes the value of one if the student changed her major and zero otherwise. We define major change in the following way (specific examples are shown in Table 1): a switch from a single major (e.g., a student with a Math major switches into a Biology major); a change of a double major to a completely different single major (e.g., a student with Biology and Math double major switches into an English major); a change of a double major to a different double major (e.g., a student with Math and Biology double major switches into English and History double major); a change of one of the majors in a double major (e.g., a student with Math and Biology double major switches into Math and English double major); and a switch of a single major to a different double major (e.g., a student with Math major switches into English and History double major). In addition, we define a major switch when a student moves between different colleges within the University, and also when a student moves from having

an undeclared major to a specific major (e.g., switch from the school of health studies to a 
business school and at the same time a student moves from being undeclared to Accounting major, or from being undeclared to Accounting and Finance double major). These cases are displayed in Table 1.

Our data includes information on the socio-demographic characteristics of students, including their gender, race, whether they are U.S. citizens or not, the type of high school they attended, their rank in high school, their verbal and math ACT and/or SAT scores, parents' educational attainment, and financial aid received from the University.

In addition, we have information for each student on the classes he/she attended in each term as well as the class composition of students and faculty in terms of race, gender, and U.S. citizenship, grade distribution in the class, and the student's final grade. We also know whether each particular class counts toward their major. We use this information to construct variables that control for majors' characteristics including grade point average (GPA), share of female classmates, share of classmates who are non-U.S. citizens, share of White/Black/Hispanic/Asian/Other Minority classmates, share of non-white faculty, share of faculty who are non-U.S. citizens, and share of female faculty. These variables are calculated using information only for classes related to student's major.

We complemented students' data with the data from the American Community Survey (ACS) for the 2009-2015 period to construct measures of returns to majors. In particular, we constructed the following measures for each major: average salaries in each major, employment rates in each major, and the share of part-time jobs in each major. The share of part-time jobs can be interpreted as identifying majors that offer more flexibility (see Bronson, 2015), but it can also be interpreted as showing little opportunity for stable full-time employment with benefits in the major.

Since the ACS major categories do not correspond exactly to the University's major categories, we matched the University's majors not listed in the ACS with similar or sometimes multiple ACS majors. ${ }^{4}$ As a measure of the expected salary for a particular major, we used

\footnotetext{
${ }^{4}$ The University's Career Center internally collects data on alumni salaries in the first half year after graduation. Thus, we also obtained Career Center's data from the alumni survey. Unfortunately, response
} 
median salary for all individuals in the ACS who graduated with that particular major and had a terminal bachelor's degree. We adjusted wages by CPI to account for inflation. About $23 \%$ of the University's students graduate with a double major. The ACS data do not contain all double majors that students choose at the University, and there are often not enough individuals with a particular double major in the ACS data to construct a credible estimate of the median wage. Thus, we use the average of the two median salaries corresponding to each major to measure the return to a double major. The employment rates and the share of part-time jobs for double majors are constructed in a similar way using the ACS data. ${ }^{5}$

For students with an undeclared major, we calculated the average of median salaries, employment rates, and shares of part-time jobs across all majors that belong to the school that the student attended (e.g., the average wage for the undeclared major in the business school is the average of median wages corresponding to all majors in the business school).

The ACS data for returns to majors are available only for 2009-2015. We extrapolated the ACS data from 2009 to 2008 to have a larger sample by assuming the growth from 20092016 and applying those growth rates backwards to $2008 .{ }^{6}$ Because we use lagged returns to majors in our analysis, we restricted our sample to 2009-2016.

We also exclude students that transferred in or out of the University because we do not

rates of this survey are low and some majors do not have enough data to obtain reliable estimates of median salaries in those majors. However, we used the Career Center's data to determine how accurate the ACS data are and how well we matched the University's majors with the ACS majors. The correlation between the two data samples is high -0.72 for the major categories for which the career center data have at least 15 observations. This high correlation suggests that the ACS majors are matched well with the University's majors and it gives us confidence in using the ACS data to construct measures of returns to majors.

${ }^{5}$ One could be concerned with this approximation because some majors may be complementary and, thus, offer a premium over the simple average of medians of salaries corresponding to two separate majors. To address this concern, we calculated the correlation between median salaries corresponding to double majors with enough observations (more than 50) in the ACS sample and average of median wages corresponding to each major in that double major. The correlation between the two measures is 0.81 . We compared similar measures for double majors for the employment rate and share of part-time jobs. The corresponding correlations are also high - 0.64 and 0.77 . These statistics suggest that while imperfect, the averages of statics corresponding to each major in a double major degree are credible approximations for the returns to double major.

${ }^{6}$ The correlation between wages in subsequent years in our sample is above 0.96 ; the correlation between employment rates in the subsequent years is above 0.88; and the correlation between the availability of part-time jobs across majors in the subsequent years is above 0.90 . Thus, extrapolation is reasonable in this context. 
observe their grades in the periods when they were not enrolled in the University. We also do not know the reasons for their transfer. In addition, we exclude students who dropped out - these are students who have not graduated and did not register for classes for more than 1.5 years. Finally, we complement our data with data on real GDP growth to control for business cycles. The data for real GDP comes from the U.S. Bureau of Economic Analysis.

\subsection{Summary Statistics}

Our final sample includes 9,180 students and 82,628 terms. The unit of observation is student in each term (e.g., Fall of 2009, Spring of 2010, or Summer of 2010). There are a total of 65 majors at the University. We split majors in four groups: female-dominated (FD) majors (i.e., majors in which more than $60 \%$ of the students are female), male-dominated (MD) majors (i.e., majors in which more than $60 \%$ of students are male), neutral majors (i.e., majors which are neither female- or male-dominated), and STEM majors. Majors included in each of these categories are reported in Table 2. Women tend to concentrate in majors in the Humanities and Languages, but also in Sociology and Psychology and in Biologyrelated STEM fields. Men tend to concentrate in majors in Business, Social Sciences, non Biology-related STEM, and in Philosophy.

Table 3 presents summary statistics of students' characteristics for the full sample and for the four groups of majors described above. The table shows that there are $2 \%$ of terms when students change their majors. Note that $80 \%$ of students stay at the University for 8 terms (excluding summer terms), therefore although the number of terms with switches is relatively small the number of students who change major at least once during their undergraduate degree is much higher - more than $12 \%$.

Paralleling the trend nationwide, the University has more female than male undergraduate students $-53 \%$ of students are women. The majority of the students are White $-67 \%$. The second largest group of students is Asian - 13\%, followed by Hispanics - 8\%, Blacks $7 \%$, and finally other races denoted as other minorities, which comprise $5 \%$ of the student 
population. About $8 \%$ of undergraduate students are non-US citizens. Around $48 \%$ of students that enter the University come from public schools, followed by the students coming from independent schools $-28 \%$, and Catholic schools $-22 \%$. The University accepts both SAT and ACT scores. For comparison purposes, we converted SAT scores into ACT scores and also reported them in the table. The University is highly selective; the average ACT score of the accepted students in English is 30.72, whereas the average ACT score in Math is $30.58 .^{7}$ About $56 \%$ of students in our data either did not apply for financial aid or did not receive it, while $8 \%$ of the students receive small amounts of financial aid, $15 \%$ of the students receive medium amounts of financial aid, and $21 \%$ percent receive large amounts of financial aid. While the aid amounts that students receive in each of these categories vary, the average financial aid is the lowest in the "low financial need" category, followed by "medium financial need" category, and the highest average aid is in "high financial need" category. Because the exact aid amounts are often missing, we do not include the precise financial aid and, instead, only use students' classification according to the 4 categories just mentioned.

Only around $26 \%$ of students enter the University with a pre-declared major. Those with pre-declared majors usually declare majors in the Sciences and in Languages. On average, $31 \%$ of students are in female-dominated majors, $22 \%$ of students are in male-dominated majors, and $28 \%$ of students are in neutral majors. The rest of the students, $29 \%$, are undeclared. When comparing descriptive statistics across the major categories, there are more switches from STEM fields - $8 \%$ of students who initially choose STEM major switch out, comparing to female-dominated majors, where only $3 \%$ of students switch out, maledominated majors $-2 \%$ of students switch out, or neutral majors $-4 \%$ of students switch out. There are 1,115 students who change their majors at least once. The majority of students, $99 \%$ switch once, and less than $1 \%$ of students switch more than one time. Out of these students, 399 are in female-dominated majors prior to the switch, 209 are in male-dominated

\footnotetext{
${ }^{7}$ These scores are around the 95 th percentile of the distribution of scores. Average national ACT scores in 2016 were 21.3 and 20.6 for reading and math, respectively.
} 
majors, 613 are in the neutral major category, and 493 students are in STEM majors.

Turning to the summary statistics across the four sub-samples, we find that despite concerns about the lack of females in STEM majors, our descriptive statistics indicate that there are exactly $50 \%$ of women in STEM majors. Table 2 indicates that among STEM majors women prefer biology-related fields, while men tend to major in physics and computer science. There are minor differences in the class composition across the major categories. There are more White and Asian students in male-dominated and STEM majors, while there are more Blacks in female-dominated majors than in other majors. There are more Hispanics in the female-dominated and neutral majors compared to male-dominated and STEM majors. Students in female-dominated majors have slightly lower English and Math ACT scores compared to students in other majors. Also, students who choose STEM majors have the highest high school ranking.

The most pronounced difference across major categories is the rate of students with predeclared majors. Fifty percent of students in female-dominated majors and $83 \%$ of students in STEM majors start college with a pre-declared major. This rate is much lower among students in neutral majors $-29 \%$, and male-dominated majors $-14 \%$. This is, however, not surprising. The University requires pre-declaring certain majors, most of which are languages (mostly female-dominated majors) and sciences (STEM). This requirement is due to a heavy course load mandatory to fulfill these majors and sometimes it is due to certain facility restrictions (e.g., seats in laboratories).

Turning to the summary statistics for major characteristics presented in Table 4, the average GPA among students is quite high - 3.4, and the GPA is slightly higher among students in FD majors compared to students in MD, neutral, and STEM majors. The highest share of classmates who are non-U.S. citizens is among students in MD majors. The share of White classmates is about the same across all major categories, the share of Black classmates is highest in FD majors, the share of Hispanic classmates is the highest in neutral majors and the lowest in STEM category; and the share of Asian classmates is highest in 
MD and STEM major categories. The share of non-White faculty is on average $12 \%$, and it is the highest in the FD major category - $14 \%$ and the lowest in the MD major category. There are about $13 \%$ of the faculty at the University who are non-U.S. citizens. The highest share of professors who are not U.S. citizens are in the MD majors - 17\%. Finally, there are about $42 \%$ of professors who are women, and the highest concentration of female faculty is in FD majors - 51\%, while the lowest is in the MD category $-32 \%$.

The descriptive statistics for returns to majors are presented at the bottom of Table 4 . While the University's brand may add a premium to the wages of graduating students and, thus, raise their salary expectations, we assume that this premium is homogenous across all majors and that the relative hierarchy of wages for the University's alumni corresponds to the one in the ACS data. Based on the ACS data, the average of the median wages across all majors during 2008-2015 is $\$ 51,661$ per year. The descriptive statistics show that the individuals in female-dominated majors may expect the lowest median salary - $\$ 46,535$ per year, while students in male-dominated majors may expect the highest salary after graduation - $\$ 58,454$ per year. The average median salary among individuals graduating with STEM majors is $\$ 53,539$ per year over $2008-2015$, and finally, students in neutral majors may expect a median wage of $\$ 52,502$ per year after graduation. The average employment rate among all majors is $81.5 \%$. The highest employment rate is among graduates of maledominated majors $-83.9 \%$, followed by neutral majors $-81.2 \%$, followed by STEM majors - 80.7\%, and finally followed by female-dominated majors $-79.3 \%$. The availability of part-time jobs is the opposite - the highest share of part-time jobs is among graduates from female-dominated majors - 21.1\%, while all other major categories have a much lower percent of available part-time jobs varying from $12 \%$ to $16 \%$.

In our empirical analysis we control for the growth of real GDP to account for business cycles. On average, the GDP grew 1.3\% over 2009-2016. 


\section{Estimation Strategy}

We analyze factors influencing students' decisions to change majors. We are particularly interested in estimating the effect of feedback about fit in the form of grades, or GPA, as well as teasing out which major characteristics influence students' decisions to stay in a major.

In our empirical model, in each term a student takes classes and gains some information about her performance in those classes, as well as the characteristics of those classes. Then, a student uses this information to update her prior knowledge about her abilities and major attributes and decides whether to keep or switch her current major.

When a student makes a decision, she compares aggregated information gained in the current term and all previous terms across different major choices. We do not know precisely which subset of majors a student compares when she makes a decision, but we observe student's current major and the subsequent major (in the case when a student switches). To model this decision-making process, we construct ratios of major characteristics that compare a student's current and subsequent majors in the case in which there is a major change. Otherwise, we compare characteristics of student's current major with the average characteristics in all majors, i.e., based on all classes that the student took up until the decision-making point. The logic behind comparing the current major and the subsequent major (when there is one) is simple. A student might consider other majors as well, but the subsequent major has the most attractive attributes and/or student's performance is the most satisfactory compared to other potential majors. Therefore, this comparison would be sufficient to identify students' preferences. When there is no subsequent major, we compare characteristics of current major with the characteristics of all classes taken up to date, i.e. student's performance and experience in a current major with the average.

The variables that student $i$ uses to compare majors and that potentially influence her 
decision are constructed in the following way:

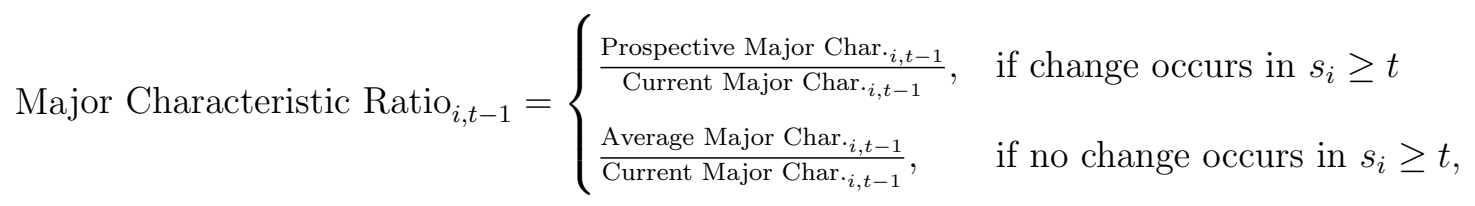

where major characteristics include variables listed in Table 4, such as GPA in major-related classes, class and faculty characteristics, and returns to major; $s$ is the time variable that equals $s_{i 1}, \ldots s_{i T_{i}}$, where $s_{1 i}$ and $s_{i T_{i}}$ are the first and last terms of student $i$ 's enrollment in the University, respectively.

To illustrate how exactly such variables are constructed, consider the following hypothetical example presented in Table 5. A student starts with a pre-declared major in Math (MATH), after two terms she switches into Computer Science (COSC), and after two more terms she switches into Physics (PHYS) and graduates with this major. To calculate GPA ratio, we first determine the current and the subsequent majors in each term. In the first two terms, the current major is MATH and the subsequent major is COSC. In terms 3 and 4, the current major is COSC and the subsequent major is PHYS. Finally, in terms 5-8 the current major is PHYS, and because there is no major change afterward, there is no prospective major. In this case the current major GPA is compared to average GPA of the student. According to equation (6), GPA Ratio in the Fall of 2009 equals to COSC GPA divided by MATH GPA, or 2.90/3.00 = 0.97. By analogy, GPA ratio in the Fall of 2010 equals to PHYS GPA divided by COSC GPA, or 3.45/3.40=1.01. Finally, the GPA ratio in the Spring of 2012 equals to average GPA divided by PHYS GPA, or 3.55/3.58 = 0.99.

Finally, to model a student's decision, we use a logit model where random errors are clustered at the student level to account for correlation across student's decisions in separate terms:

$$
\text { Switch }{ }_{i t}=f\left(\text { Female }, X_{i}, Z_{i, t-1}, W_{i, t-1}, I M_{i, t-1}\right)+\epsilon_{i t} \text {, }
$$


where $X_{i}$ is a vector of time-invariant socio-demographic characteristics of student $i ; Z_{i, t-1}$ is a vector of ratios of major characteristics for student $i$ in time period $t-1 ; W_{i, t-1}$ is a vector of ratios of returns to major for student $i$ in time $t-1 ; I M_{i, t-1}$ is a vector of indicators that student $i$ is in female-dominated, male-dominated, neutral, or STEM major in time $t-1$; and finally, $\epsilon_{i t}$ is an unobserved taste of individual $i$ in time $t$. Note that while female-dominated, male-dominated, and neutral majors are mutually exclusive categories, STEM majors can be either male-dominated, female-dominated, or neutral (see classification in Table 2).

\section{The Impacts of Signals of 'Fit' and other Factors on Major Choice}

We estimate models with the following set of controls: (1) demographic characteristics of students and pre-college performance; (2) demographic characteristics, pre-college performance and major characteristics (GPA, faculty and student composition, and returns to major) and interactions of characteristics of theoretical interest with a female dummy; (3) demographic characteristics, major characteristics, a female/male-dominated major dummy and multiple two-level interactions of the female dummy and the FD/MD major indicators with major GPA, major returns and the share of female classmates, and (4) a STEM major dummy and various two- and three-way interactions of the STEM major dummy, female dummy, major GPA, and major characteristics. The idea of including the interaction terms is to examine whether female students respond differently to various factors than their male counterparts.

The results from the first three models are presented in Table 6, and the estimation results of the fourth model are presented in Table $7 .^{8}$ Tables 6 and 7 show that we are able to explain between $15 \%$ of variation in major switches in the simplest model and $29 \%$ of variation in the dependent variable in the most complex model, which indicates that

\footnotetext{
${ }^{8}$ Note that the full sets of results are reported in Appendix Tables A1 and A2.
} 
unobserved factors (including potentially preferences) play a big role.

Column (1) in Table 6 shows that some of the effects of the demographic characteristics matter, but overall these are not very important. Interestingly, women are no more likely to switch majors than men. Different demographic groups (Hispanics, Asians, and other minorities) are no more likely to change majors with the exception of Blacks who appear more likely to switch in one of the specifications. On the other hand, non-citizens are more likely to switch majors than natives. However, this effect goes away when we control for major characteristics. These models also include pre-college preparation measured by ACT scores in English and Math (not reported in Table 6, but reported in Table A1). We find that pre-college academic preparation has no significant impact on major changes, which contrasts with previous work that finds a small but significant effect of pre-college preparation. Not surprisingly, those with pre-declared majors are more likely to switch.

Column (2) in Table 6 shows that the ratio of the subsequent major's GPA to the current major's GPA is significant and positive. This means that students are more likely to switch into a field in which their grades improve. The interaction with a female dummy is insignificant, indicating that women are no more likely than men to switch majors in response to negative feedback about their performance. This means that both women and men are as likely to respond to low grades by switching to a different major.

Column (2) in Table 6 also shows that female teachers and female classmates do not affect major switches and, more surprisingly, female students do not respond more to female faculty or classmates. Thus, we find no support for female faculty serving as role models for female students and attracting or helping to keep female students in a major. We also find no impact of other faculty characteristics that would significantly impact switching decisions. However, we find some impact of class composition on switching patterns. In particular, Appendix Table 1 shows that students are more likely to switch into majors with higher shares of Hispanics.

Column (2) also includes three measures of returns to a field. We find evidence that 
higher earnings in a field and lower employment rates discourage students from going into that field. Although, the significance of the coefficient for wages goes away when we control for additional variables that capture class composition. We find that availability of part-time jobs does not significantly affect persistence in a major. The effects of returns to a major are no different for men and women. These results are consistent with some of the previous findings in the literature which show that preferences for workplace characteristics are much more important than returns in determining choice of major.

Model (3) of Table 6 includes an indicator of whether the major is dominated by men as well as interactions of this indicator with the student's gender, GPA ratio and returns to a major. We find that students in male-dominated fields are more likely to switch out when they have more female classmates and this is true for both men and women. Thus, while we did not find evidence on faculty affecting choice of major in column (2), we find that classmates affect major switches in column (3). The results in column (3) show that students in male-dominated majors are no more likely to change majors than students in neutral majors, and women are less likely to switch out of a male-dominated majors compared to men. Importantly, the results in column (3) show that women are no more likely to opt out of male-dominated major in response to negative feedback from lower grades. Figure 1 (a) plots probabilities to switch out of male-dominated majors in response to bad grades for women and men. The difference in probabilities between genders is only marginal and it is not statistically significant (the confidence intervals for the two overlap). Therefore, we cannot confirm that women are, in general, deterred from male-dominated majors by poor performance.

Next in column (3) of Table 6 , we look at female-dominated majors to see if men behave similarly to women when they are the minority gender in the major. The results show that students are less likely to switch out of female-dominated majors compared to neutral and male-dominated majors. However, men are less likely to switch out of female-dominated fields compared to women. Finally, women with low grades are less likely to switch out of 
female-dominated fields compared to men in a similar situation. We plot the probabilities of a major switch for women and men in response to grades in Figure 1 (b). The figure clearly shows that men are more likely to switch out of female-dominated fields when they have low grades. Contrary to perceptions about women's over-sensitivity to negative feedback, these results show that women, if anything, are less responsive to bad grades than men.

The last row in columns (2) and (3) of Table 6 shows that switching increases in response to higher employment in a major as economic conditions get worse. Similar to previous literature, we find that students pay more attention to returns to a major when the economy is going through a downturn. ${ }^{9}$

In Table 7 , we specifically examine STEM fields. First, we find that both male and female students are less likely to opt out of STEM majors. We next explore if either gender is more likely to switch out of STEM in response to low grades when the STEM major is dominated by either gender. We include interactions of STEM field indicator with an indicator of whether the STEM major is dominated by women or men, a female dummy, and a ratio of GPA in prospective major to GPA in current major. We first plot the propensities to switch major for women and men when they are in a male-dominated STEM major. We find that while women are no more likely to switch out of a male-dominated STEM major (Figure 1(a)), they are significantly more likely to switch out of a male-dominated STEM major if they have a low GPA (Figure 1(c)). Next, we plot the women's and men's propensities to switch out of female-dominated STEM major. We find that men are more likely to switch out of a female-dominated STEM field when they can improve their grades (Figure 1(b)), however, they are no more likely to switch out of female-dominated STEM field in response to low grades compared to women (Figure $1(\mathrm{~d})) .{ }^{10}$

\footnotetext{
${ }^{9}$ While not reported in the table, we tried triple interaction of this effect with the female dummy and we find no differential between women's and men's responses to returns during downturns.

${ }^{10}$ This last result should be interpreted with caution. As seen in Figure 1(d), the confidence intervals are rather large which indicates that there are might not be enough switches of women out of female-dominated STEM fields. In total, 30 students in our sample switch out of STEM FD majors, among them 18 are females and 12 are males. Therefore, while the results fit our theory well, we cannot state with certainty that these results are significant due to sample size restrictions.
} 
Based on these results, we conclude that the current policy focus on increasing women in STEM fields might have paradoxically strengthened the associated masculinity of STEM majors. Therefore, male students feel more confident about succeeding in STEM majors compared to female students even when their grades are low. If female students believe that men are inherently a better fit for STEM majors, and those female students also see their numerical minority status, they are more likely to perceive their low grades as confirmation about their unfitness for their male-dominated STEM major. Thus, it takes three concurrent signals for women to be dissuaded from undertaking majors more than men. Specifically, only when women are in a male-dominated STEM field are they more responsive than men to the negative feedback of low grades.

Interestingly, we find that the ACT scores in Math decrease the likelihood of switching out of a major (results reported in Table A2). However, we interpret this result with caution because the impact of the ACT scores was insignificant in all the previous models. ${ }^{11}$

\section{Conclusion}

In this paper, we analyze the determinants of major switching behaviors among undergraduate students. Our main focus is on signals of fit in the major on the decision to switch, after controlling for all other factors (including high school preparation, socio-economic background, gender composition of faculty and classmates, and returns to major). While some previous literature has suggested that women are more responsive to negative feedback than men, we find little evidence of this. Instead, we find that both men and women respond to signals of ability in a major by moving away from it when they receive low relative grades. We also find that men and women respond similarly to low relative grades when they are in male-dominated fields, so that even if women receive a second signal about their lack of fit in

\footnotetext{
${ }^{11} \mathrm{We}$ also tried to include in our model the interaction of the ACT scores with female dummy to test if pre-college preparation has different impact on males and females but we did not find any significant differences.
} 
the form of low representation in the field they are still not dissuaded more than men from staying in the field. ${ }^{12}$ Rather, we find that it is only when women are in male-dominated STEM fields, which themselves are associated with masculinity (Francis et al. (2017)), that women are less likely to persist in response to low grades than men. Although prior research on stereotype threat ${ }^{13}$ finds that women's behavior is responsive to cues that they might underperform on masculine tasks (Spencer et al. (1999); Campbell and Collaer (2009)), we find no evidence of women switching more often simply because of a low grades in a masculine domain. The stereotype that STEM fields are masculine serves to turn women away from these majors only when coupled with two other signals suggesting women's lack of fit.

Additionally, we find little evidence that faculty role models and previous preparation are important factors for either men or women, so that increasing female faculty in maledominated STEM fields may not help nor will additional preparation prior to coming to college. On the other hand, we do find that higher earnings in a field attract both men and women to male-dominated majors. Thus, providing information on returns can help to change the composition of the field to having more women. Yet, as fields become lower paying with the entrance of more women in those fields (Blau and Kahn (2006)), then naturally the attraction of a higher return dissipates. Therefore, in the longer term attracting women to fields in which they are under-represented might require greater progress on equal pay for equal work initiatives.

\footnotetext{
${ }^{12}$ By the time students get to college, thus, women appear no more likely to respond to low grades relative to men. By contrast, Lavy and Sand (2015) find that teacher's gender biases during middle and high school negatively impacts students' enrollment in advanced level math courses in high school.

${ }^{13}$ Stereotype threat occurs when a stigmatized group worries about lower performance on a stereotyped task (Steele and Aronson (1995)).
} 


\section{Table 1: Examples of Major Switch}

\begin{tabular}{lllll}
\hline \hline MATH & $\rightarrow$ & BIOL & & \\
MATH BIOL & $\rightarrow$ & ENGL & & \\
MATH BIOL & $\rightarrow$ & ENGL HIST & & \\
MATH BIOL & $\rightarrow$ & MATH ENGL & & \\
MATH & $\rightarrow$ & ENGL HIST & & \\
UNDE & $\rightarrow$ & ACCT & $\&$ & College Switch \\
UNDE & $\rightarrow$ & ACCT FINC & $\&$ & College Switch \\
\hline \hline
\end{tabular}

Table 2: Major Categories

\begin{tabular}{|c|c|c|c|}
\hline FD Majors & Neutral Majors & MD Majors & STEM Majors \\
\hline American studies & American Musical Culture & Accounting & Biochemistry $(\mathrm{N})$ \\
\hline Anthropology & Biochemistry & Biophysics & Biology $(\mathrm{N})$ \\
\hline Arabic & Biology & Computer Science & Biology of Global Health (FD) \\
\hline Art (Studio) & Chemistry & Economics & Biophysics (MD) \\
\hline Art history & Classics & Finance & Chemistry $(\mathrm{N})$ \\
\hline Biology of Global Health & Early Childhood Education & Global Business & Computer Science (MD) \\
\hline Chinese & Government & History & Environmental Biology (FD) \\
\hline Comparative Literature & Interdisciplinary Studies & International Business & Mathematics (N) \\
\hline Culture and Politics & International Business & International Economics & Neurobiology (FD) \\
\hline English & International Business Regional Studies & International History & Physics (MD) \\
\hline Environmental Biology & International Political Economy Business & International Political Economy & \\
\hline French & International Politics & Management-business & \\
\hline German & Japanese & Operations Information Management & \\
\hline Health Care Management \& Policy & Marketing & Philosophy & \\
\hline Health Studies & Mathematics & Physics & \\
\hline Human Science & Medieval Studies & Political Economy & \\
\hline International Health & Regional and Comparative Studies & & \\
\hline Italian & Russian & & \\
\hline Justice and Peace studies & Theater and Performance & & \\
\hline \multicolumn{4}{|l|}{ Linguistics Theology } \\
\hline \multicolumn{4}{|l|}{ Neurobiology } \\
\hline \multicolumn{4}{|l|}{ Nursing } \\
\hline \multicolumn{4}{|l|}{ Portuguese } \\
\hline \multicolumn{4}{|l|}{ Psychology } \\
\hline \multicolumn{4}{|l|}{ Science, Technology, and } \\
\hline \multicolumn{4}{|l|}{ International Affairs } \\
\hline \multicolumn{4}{|l|}{ Sociology } \\
\hline \multicolumn{4}{|l|}{ Spanish } \\
\hline \multicolumn{4}{|l|}{ Spanish \& Portugese } \\
\hline Women's and Gender Studies & & & \\
\hline
\end{tabular}


Table 3: Summary statistics

\begin{tabular}{|c|c|c|c|c|c|}
\hline \multirow[t]{2}{*}{ Variable } & $2008-2016$ & FD Major & Neutral Major & MD Major & \multirow{2}{*}{$\begin{array}{c}\text { STEM Major } \\
\text { Mean/Std. Dev. }\end{array}$} \\
\hline & Mean/ Std. Dev. & Mean/ Std. Dev. & Mean/ Std. Dev. & Mean/ Std. Dev. & \\
\hline $\begin{array}{l}\text { Student Characteristics } \\
\text { Switch }\end{array}$ & $\begin{array}{c}\mathbf{0 . 0 2 0} \\
{[0.139]}\end{array}$ & $\begin{array}{l}0.028 \\
{[0.163]}\end{array}$ & $\begin{array}{c}0.043 \\
{[0.202]}\end{array}$ & $\begin{array}{c}\mathbf{0 . 0 2 3} \\
{[0.151]}\end{array}$ & $\begin{array}{c}\mathbf{0 . 0 8 1} \\
{[0.272]}\end{array}$ \\
\hline Female & $\begin{array}{c}\mathbf{0 . 5 3 0} \\
{[0.499]}\end{array}$ & $\begin{array}{l}\mathbf{0 . 7 1 9} \\
{[0.450]}\end{array}$ & $\begin{array}{c}0.495 \\
{[0.500]}\end{array}$ & $\begin{array}{c}\mathbf{0 . 3 5 1} \\
{[0.477]}\end{array}$ & $\begin{array}{c}0.504 \\
{[0.500]}\end{array}$ \\
\hline White & $\begin{array}{c}\mathbf{0 . 6 7 2} \\
{[0.470]}\end{array}$ & $\begin{array}{l}\mathbf{0 . 6 6 8} \\
{[0.471]}\end{array}$ & $\begin{array}{l}\mathbf{0 . 6 8 5} \\
{[0.464]}\end{array}$ & $\begin{array}{c}\mathbf{0 . 6 9 9} \\
{[0.459]}\end{array}$ & $\begin{array}{l}\mathbf{0 . 7 0 7} \\
{[0.455]}\end{array}$ \\
\hline Black & $\begin{array}{c}0.071 \\
{[0.257]}\end{array}$ & $\begin{array}{c}\mathbf{0 . 0 8 9} \\
{[0.285]}\end{array}$ & $\begin{array}{c}\mathbf{0 . 0 6 5} \\
{[0.246]}\end{array}$ & $\begin{array}{c}\mathbf{0 . 0 4 3} \\
{[0.202]}\end{array}$ & $\begin{array}{c}0.050 \\
{[0.218]}\end{array}$ \\
\hline Hispanic & $\begin{array}{l}0.078 \\
{[0.268]}\end{array}$ & $\begin{array}{c}0.078 \\
{[0.268]}\end{array}$ & $\begin{array}{c}0.080 \\
{[0.272]}\end{array}$ & $\begin{array}{c}\mathbf{0 . 0 6 5} \\
{[0.247]}\end{array}$ & $\begin{array}{c}\mathbf{0 . 0 5 1} \\
{[0.219]}\end{array}$ \\
\hline Asian & $\begin{array}{c}\mathbf{0 . 1 3 0} \\
{[0.336]}\end{array}$ & $\begin{array}{c}\mathbf{0 . 1 1 2} \\
{[0.315]}\end{array}$ & $\begin{array}{c}\mathbf{0 . 1 2 4} \\
{[0.330]}\end{array}$ & $\begin{array}{c}\mathbf{0 . 1 5 6} \\
{[0.363]}\end{array}$ & $\begin{array}{c}\mathbf{0 . 1 4 5} \\
{[0.353]}\end{array}$ \\
\hline Other Minority & $\begin{array}{c}0.049 \\
{[0.216]}\end{array}$ & $\begin{array}{c}0.053 \\
{[0.224]}\end{array}$ & $\begin{array}{l}\mathbf{0 . 0 4 6} \\
{[0.209]}\end{array}$ & $\begin{array}{c}0.038 \\
{[0.190]}\end{array}$ & $\begin{array}{c}\mathbf{0 . 0 4 7} \\
{[0.211]}\end{array}$ \\
\hline Non-Citizen & $\begin{array}{c}\mathbf{0 . 0 8 2} \\
{[0.276]}\end{array}$ & $\begin{array}{c}0.055 \\
{[0.228]}\end{array}$ & $\begin{array}{c}\mathbf{0 . 0 7 4} \\
{[0.261]}\end{array}$ & $\begin{array}{l}\mathbf{0 . 1 0 7} \\
{[0.310]}\end{array}$ & $\begin{array}{c}\mathbf{0 . 0 5 7} \\
{[0.233]}\end{array}$ \\
\hline ACT Math & $\begin{array}{c}\mathbf{3 0 . 5 6 9} \\
{[3.378]}\end{array}$ & $\begin{array}{c}\mathbf{2 9 . 9 5 6} \\
{[3.437]}\end{array}$ & $\begin{array}{c}\mathbf{3 0 . 6 5 5} \\
{[3.250]}\end{array}$ & $\begin{array}{c}\mathbf{3 1 . 5 1 7} \\
{[3.006]}\end{array}$ & $\begin{array}{c}\mathbf{3 1 . 1 2 5} \\
{[2.663]}\end{array}$ \\
\hline HS Rank & $\begin{array}{l}\mathbf{9 4 . 8 2 4} \\
{[7.272]}\end{array}$ & $\begin{array}{l}\mathbf{9 4 . 9 7 1} \\
{[6.746]}\end{array}$ & $\begin{array}{l}\mathbf{9 4 . 8 1 7} \\
{[7.215]}\end{array}$ & $\begin{array}{l}\mathbf{9 4 . 6 6 6} \\
{[7.415]}\end{array}$ & $\begin{array}{l}\mathbf{9 6 . 2 5 9} \\
{[4.544]}\end{array}$ \\
\hline Independ. School & $\begin{array}{c}\mathbf{0 . 2 8 2} \\
{[0.450]}\end{array}$ & $\begin{array}{c}\mathbf{0 . 2 8 3} \\
{[0.451]}\end{array}$ & $\begin{array}{c}\mathbf{0 . 2 7 3} \\
{[0.445]}\end{array}$ & $\begin{array}{c}\mathbf{0 . 2 8 1} \\
{[0.450]}\end{array}$ & $\begin{array}{c}\mathbf{0 . 2 5 4} \\
{[0.435]}\end{array}$ \\
\hline Public School & $\begin{array}{c}\mathbf{0 . 4 8 3} \\
{[0.500]}\end{array}$ & $\begin{array}{c}\mathbf{0 . 4 8 3} \\
{[0.500]}\end{array}$ & $\begin{array}{c}\mathbf{0 . 4 9 4} \\
{[0.500]}\end{array}$ & $\begin{array}{c}\mathbf{0 . 4 7 4} \\
{[0.499]}\end{array}$ & $\begin{array}{c}\mathbf{0 . 4 6 9} \\
{[0.499]}\end{array}$ \\
\hline Catholic School & $\begin{array}{c}\mathbf{0 . 2 2 1} \\
{[0.415]}\end{array}$ & $\begin{array}{c}\mathbf{0 . 2 2 3} \\
{[0.416]}\end{array}$ & $\begin{array}{c}\mathbf{0 . 2 2 2} \\
{[0.415]}\end{array}$ & $\begin{array}{c}\mathbf{0 . 2 3 0} \\
{[0.421]}\end{array}$ & $\begin{array}{c}\mathbf{0 . 2 7 2} \\
{[0.445]}\end{array}$ \\
\hline Other School & $\begin{array}{c}\mathbf{0 . 0 1 3} \\
{[0.113]}\end{array}$ & $\begin{array}{c}\mathbf{0 . 0 1 1} \\
{[0.103]}\end{array}$ & $\begin{array}{c}\mathbf{0 . 0 1 2} \\
{[0.107]}\end{array}$ & $\begin{array}{c}\mathbf{0 . 0 1 5} \\
{[0.120]}\end{array}$ & $\begin{array}{c}\mathbf{0 . 0 0 4} \\
{[0.063]}\end{array}$ \\
\hline No Fin. Need & $\begin{array}{c}\mathbf{0 . 5 5 6} \\
{[0.497]}\end{array}$ & $\begin{array}{c}\mathbf{0 . 5 1 9} \\
{[0.500]}\end{array}$ & $\begin{array}{c}\mathbf{0 . 5 3 3} \\
{[0.499]}\end{array}$ & $\begin{array}{c}\mathbf{0 . 5 9 2} \\
{[0.491]}\end{array}$ & $\begin{array}{c}\mathbf{0 . 5 5 9} \\
{[0.497]}\end{array}$ \\
\hline Low Fin. Need & $\begin{array}{c}\mathbf{0 . 0 8 7} \\
{[0.282]}\end{array}$ & $\begin{array}{c}\mathbf{0 . 0 8 7} \\
{[0.282]}\end{array}$ & $\begin{array}{c}\mathbf{0 . 0 9 1} \\
{[0.287]}\end{array}$ & $\begin{array}{c}\mathbf{0 . 0 8 9} \\
{[0.285]}\end{array}$ & $\begin{array}{c}\mathbf{0 . 0 9 0} \\
{[0.286]}\end{array}$ \\
\hline High Fin. Need & $\begin{array}{c}\mathbf{0 . 2 1 4} \\
{[0.410]}\end{array}$ & $\begin{array}{c}\mathbf{0 . 2 5 0} \\
{[0.433]}\end{array}$ & $\begin{array}{c}\mathbf{0 . 2 1 7} \\
{[0.412]}\end{array}$ & $\begin{array}{c}\mathbf{0 . 1 8 1} \\
{[0.385]}\end{array}$ & $\begin{array}{c}\mathbf{0 . 1 7 9} \\
{[0.384]}\end{array}$ \\
\hline Predeclared Major & $\begin{array}{c}\mathbf{0 . 2 5 6} \\
{[0.436]}\end{array}$ & $\begin{array}{c}\mathbf{0 . 4 9 4} \\
{[0.500]}\end{array}$ & $\begin{array}{c}\mathbf{0 . 2 9 1} \\
{[0.454]}\end{array}$ & $\begin{array}{c}\mathbf{0 . 1 3 6} \\
{[0.343]}\end{array}$ & $\begin{array}{c}\mathbf{0 . 8 2 7} \\
{[0.378]}\end{array}$ \\
\hline Female-Dominated Major & $\begin{array}{c}\mathbf{0 . 3 1 0} \\
{[0.463]}\end{array}$ & $\begin{array}{l}- \\
-\end{array}$ & $\begin{array}{l}- \\
-\end{array}$ & $\begin{array}{l}- \\
-\end{array}$ & $\begin{array}{c}\mathbf{0 . 2 4 3} \\
{[0.429]}\end{array}$ \\
\hline Male-Dominated Major & $\begin{array}{c}\mathbf{0 . 2 1 9} \\
{[0.414]}\end{array}$ & $\begin{array}{l}- \\
-\end{array}$ & $\begin{array}{l}- \\
-\end{array}$ & $\begin{array}{l}- \\
-\end{array}$ & $\begin{array}{c}\mathbf{0 . 2 2 3} \\
{[0.417]}\end{array}$ \\
\hline Neutral Major & $\begin{array}{c}\mathbf{0 . 2 7 6} \\
{[0.447]}\end{array}$ & $\begin{array}{l}- \\
- \\
\end{array}$ & $\begin{array}{l}- \\
- \\
\end{array}$ & $\begin{array}{l}- \\
- \\
\end{array}$ & $\begin{array}{c}\mathbf{0 . 6 2 6} \\
{[0.484]} \\
\end{array}$ \\
\hline $\mathrm{N}$ obs & 82,628 & 25,633 & 22,795 & 18,131 & 9,168 \\
\hline
\end{tabular}


Table 4: Summary statistics

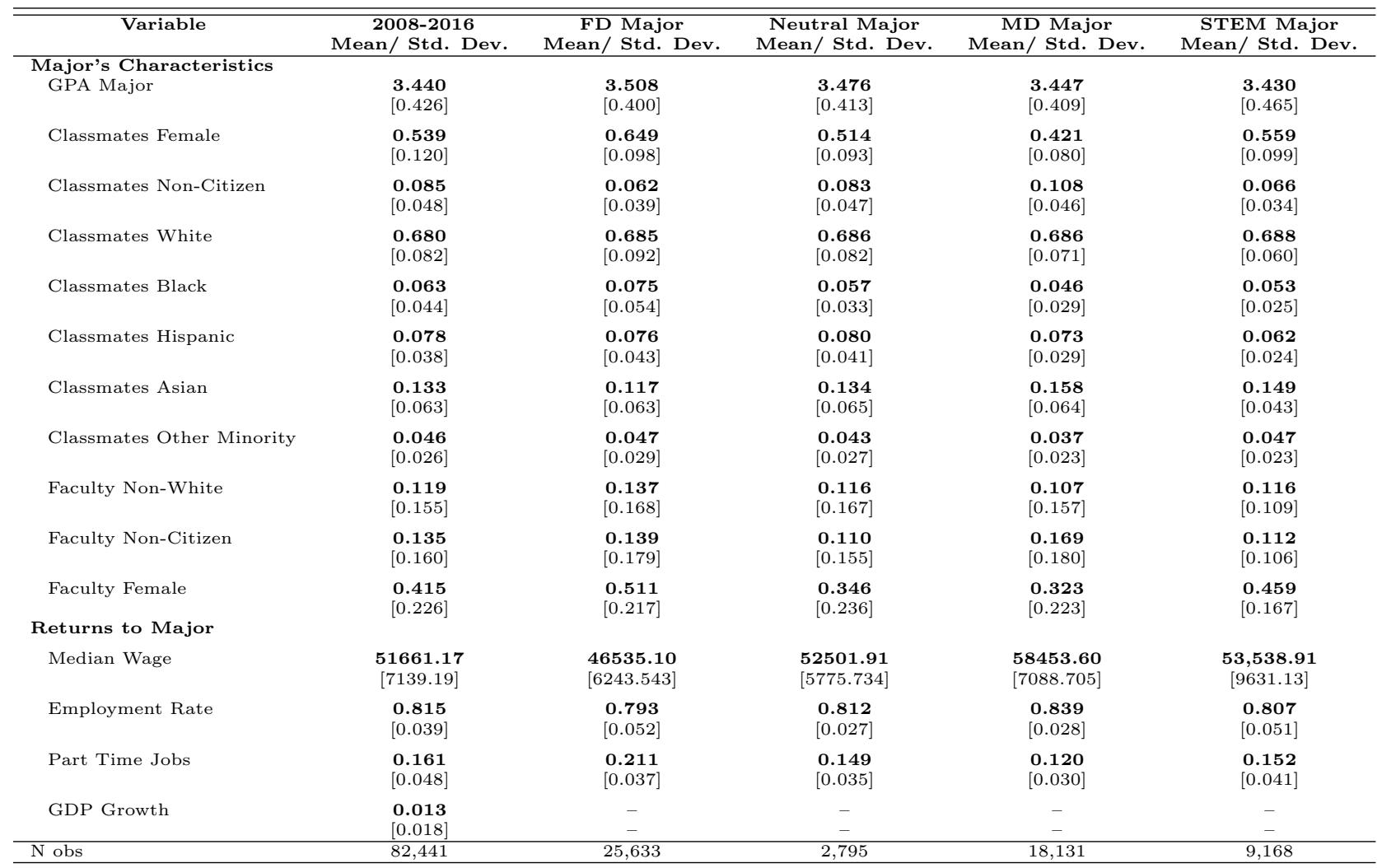

Table 5: Example of Ratio Variables Calculation

\begin{tabular}{cllccccc}
\hline \hline Student ID & \multicolumn{1}{c}{ Term } & Major & MATH GPA & COSC GPA & PHYS GPA & Average GPA & GPA Ratio \\
\hline 46 & Fall 2009 & MATH & 3.00 & 2.90 & 3.20 & 3.40 & 0.97 \\
46 & Spring 2010 & MATH & 3.10 & 3.30 & 3.40 & 3.30 & 1.06 \\
46 & Fall 2010 & COSC & 3.20 & 3.40 & 3.45 & 3.20 & 1.01 \\
46 & Spring 2011 & COSC & 3.20 & 3.40 & 3.55 & 3.50 & 1.04 \\
46 & Fall 2011 & PHYS & 3.43 & 3.43 & 3.57 & 3.45 & 0.97 \\
46 & Spring 2012 & PHYS & 3.44 & 3.44 & 3.58 & 3.55 & 0.99 \\
46 & Fall 2012 & PHYS & 3.22 & 3.22 & 3.52 & 3.48 & 0.99 \\
46 & Spring 2013 & PHYS & 3.60 & 3.60 & 3.60 & 3.56 & 0.99 \\
\hline \hline
\end{tabular}


Table 6: Estimation Results. Switch. 2008-2016

\begin{tabular}{|c|c|c|c|}
\hline & $\begin{array}{c}(1) \\
\text { Switch } \\
\beta / \mathrm{SE}\end{array}$ & $\begin{array}{l}(2) \\
\text { Switch } \\
\beta / \mathrm{SE}\end{array}$ & $\begin{array}{l}(3) \\
\text { Switch } \\
\beta / \mathrm{SE}\end{array}$ \\
\hline Female & $\begin{array}{l}-0.005 \\
(0.027)\end{array}$ & $\begin{array}{c}0.316 \\
(1.588)\end{array}$ & $\begin{array}{l}-1.364 \\
(1.836)\end{array}$ \\
\hline Non-citizen & $\begin{array}{l}0.126^{* *} \\
(0.058)\end{array}$ & $\begin{array}{l}-0.003 \\
(0.111)\end{array}$ & $\begin{array}{l}-0.010 \\
(0.116)\end{array}$ \\
\hline Hispanic & $\begin{array}{c}0.041 \\
(0.052)\end{array}$ & $\begin{array}{c}0.060 \\
(0.096)\end{array}$ & $\begin{array}{c}0.030 \\
(0.098)\end{array}$ \\
\hline Black & $\begin{array}{c}0.089 \\
(0.057)\end{array}$ & $\begin{array}{c}0.181^{*} \\
(0.097)\end{array}$ & $\begin{array}{l}0.148 \\
(0.103)\end{array}$ \\
\hline Asian & $\begin{array}{c}0.035 \\
(0.041)\end{array}$ & $\begin{array}{l}-0.024 \\
(0.072)\end{array}$ & $\begin{array}{l}-0.018 \\
(0.073)\end{array}$ \\
\hline Other Minority & $\begin{array}{c}0.017 \\
(0.058)\end{array}$ & $\begin{array}{l}-0.114 \\
(0.111)\end{array}$ & $\begin{array}{l}-0.098 \\
(0.113)\end{array}$ \\
\hline Predeclared Major & $\begin{array}{l}0.965^{* * *} \\
(0.027)\end{array}$ & $\begin{array}{l}1.079^{* * *} \\
(0.065)\end{array}$ & $\begin{array}{l}1.279^{* * *} \\
(0.081)\end{array}$ \\
\hline GPA Major Ratio $t-1$ & & $\begin{array}{l}1.488^{* * *} \\
(0.440)\end{array}$ & $\begin{array}{l}1.186^{* *} \\
(0.490)\end{array}$ \\
\hline Classmates Females Ratio $t-1$ & & $\begin{array}{l}-0.105 \\
(0.276)\end{array}$ & $\begin{array}{c}0.283 \\
(0.205)\end{array}$ \\
\hline Faculty Female Ratio ${ }_{t-1}$ & & $\begin{array}{c}0.053 \\
(0.069)\end{array}$ & $\begin{array}{c}0.039 \\
(0.076)\end{array}$ \\
\hline Median Wage Ratio ${ }_{t-1}$ & & $\begin{array}{l}-0.925^{* *} \\
(0.426)\end{array}$ & $\begin{array}{l}-0.730 \\
(0.475)\end{array}$ \\
\hline Employment Rate Ratio $t-1$ & & $\begin{array}{l}2.119^{* *} \\
(1.035)\end{array}$ & $\begin{array}{l}2.315^{* *} \\
(1.173)\end{array}$ \\
\hline Part Time Jobs Ratio $t-1$ & & $\begin{array}{l}-0.266 \\
(0.214)\end{array}$ & $\begin{array}{l}-0.229 \\
(0.246)\end{array}$ \\
\hline Female $\times$ GPA Major Ratio $t-1$ & & $\begin{array}{l}-0.590 \\
(0.493)\end{array}$ & $\begin{array}{l}-0.492 \\
(0.592)\end{array}$ \\
\hline Female $\times$ Classmates Females Ratio $t-1$ & & $\begin{array}{l}-0.027 \\
(0.456)\end{array}$ & $\begin{array}{c}0.102 \\
(0.356)\end{array}$ \\
\hline Female $\times$ Faculty Female Ratio $t-1$ & & $\begin{array}{l}-0.148 \\
(0.099)\end{array}$ & $\begin{array}{l}-0.134 \\
(0.101)\end{array}$ \\
\hline Female $\times$ Median Wage Ratio $t-1$ & & $\begin{array}{l}-0.180 \\
(0.570)\end{array}$ & $\begin{array}{c}0.815 \\
(0.590)\end{array}$ \\
\hline Female $\times$ Employment Rate Ratio $_{t-1}$ & & $\begin{array}{c}0.228 \\
(1.127)\end{array}$ & $\begin{array}{c}0.851 \\
(1.331)\end{array}$ \\
\hline Female $\times$ Part Time Jobs Ratio $t-1$ & & $\begin{array}{c}0.310 \\
(0.269)\end{array}$ & $\begin{array}{c}0.322 \\
(0.329)\end{array}$ \\
\hline Male-Dominated Major $_{t-1}$ & & & $\begin{array}{c}0.366 \\
(1.845)\end{array}$ \\
\hline Female $\times$ Male-Dominated Major $_{t-1}$ & & & $\begin{array}{l}-4.961^{*} \\
(2.893)\end{array}$ \\
\hline Male-Dominated Major $_{t-1} \times$ Classmates Females Ratio $t-1$ & & & $\begin{array}{l}-1.663^{*} \\
(0.875)\end{array}$ \\
\hline Female $\times$ Male-Dominated Major ${ }_{t-1} \times$ GPA Major Ratio $t-1$ & & & $\begin{array}{l}6.044^{* *} \\
(2.831)\end{array}$ \\
\hline Female $\times$ Male-Dominated Major $t-1 \times$ Classmates Females Ratio $t-1$ & & & $\begin{array}{l}-0.865 \\
(1.416)\end{array}$ \\
\hline Female-Dominated Major ${ }_{t-1}$ & & & $\begin{array}{l}-4.780^{*} \\
(2.728)\end{array}$ \\
\hline Female $\times$ Female-Dominated Major $_{t-1}$ & & & $\begin{array}{l}9.850^{* * *} \\
(3.272)\end{array}$ \\
\hline Female-Dominated Major ${ }_{t-1} \times$ GPA Major Ratio $_{t-1}$ & & & $\begin{array}{l}4.826^{* * *} \\
(1.500)\end{array}$ \\
\hline 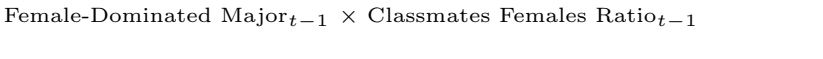 & & & $\begin{array}{c}0.507 \\
(1.325)\end{array}$ \\
\hline Female-Dominated Major ${ }_{t-1} \times$ Median Wage Ratio $_{t-1}$ & & & $\begin{array}{l}-0.666 \\
(1.321)\end{array}$ \\
\hline Female $\times$ Female-Dominated Major $_{t-1} \times$ GPA Major Ratio $t-1$ & & & $\begin{array}{l}-4.807^{* * *} \\
(1.565)\end{array}$ \\
\hline Female $\times$ Female-Dominated Major ${ }_{t-1} \times$ Classmates Females Ratio $t-1$ & & & $\begin{array}{l}-2.242 \\
(1.785)\end{array}$ \\
\hline 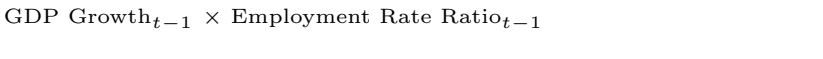 & & $\begin{array}{l}-118.959^{* * *} \\
(41.640)\end{array}$ & $\begin{array}{l}-134.766^{* * *} \\
(43.778)\end{array}$ \\
\hline Observations & 42,934 & 15,466 & 15,466 \\
\hline Pseudo $R^{2}$ & 0.15 & 0.19 & 0.22 \\
\hline
\end{tabular}

Note: $\star$ Significant at 10 percent; $\star \star$ Significant at 5 percent; $\star \star \star$ Significant at 1 percent. Standard errors in parentheses. Variables not reported in the table include need band, school type dummies, ACT scores in English and Math, and constant 
Table 7: Estimation Results. Switch. 2008-2016

\begin{tabular}{|c|c|}
\hline & $\begin{array}{c}(1) \\
\text { Switch } \\
\beta / \mathrm{SE}\end{array}$ \\
\hline Female & $\begin{array}{l}0.969 \\
(2.167)\end{array}$ \\
\hline Non-citizen & $\begin{array}{l}-0.002 \\
(0.124)\end{array}$ \\
\hline Hispanic & $\begin{array}{c}0.021 \\
(0.104)\end{array}$ \\
\hline Black & $\begin{array}{l}0.096 \\
(0.109)\end{array}$ \\
\hline Asian & $\begin{array}{c}0.011 \\
(0.077)\end{array}$ \\
\hline Other Minority & $\begin{array}{l}-0.068 \\
(0.117)\end{array}$ \\
\hline Predeclared Major & $\begin{array}{l}0.616^{* * *} \\
(0.122)\end{array}$ \\
\hline GPA Major Ratio $t-1$ & $\begin{array}{c}0.469 \\
(0.557)\end{array}$ \\
\hline Median Wage Ratio $t-1$ & $\begin{array}{l}-0.931 \\
(0.707)\end{array}$ \\
\hline Employment Rate Ratio $t-1$ & $\begin{array}{c}0.901 \\
(1.397)\end{array}$ \\
\hline Part Time Jobs Ratio $t-1$ & $\begin{array}{l}-0.246 \\
(0.262)\end{array}$ \\
\hline Female $\times$ GPA Major Ratio $t-1$ & $\begin{array}{l}-1.245 \\
(0.912)\end{array}$ \\
\hline Male-Dominated Major $t-1$ & $\begin{array}{c}2.481 \\
(1.944)\end{array}$ \\
\hline Female $\times$ Male-Dominated Major $_{t-1}$ & $\begin{array}{l}-3.531 \\
(3.227)\end{array}$ \\
\hline Male-Dominated Major $_{t-1} \times$ GPA Major Ratio $_{t-1}$ & $\begin{array}{c}1.444 \\
(1.556)\end{array}$ \\
\hline Female $\times$ Male-Dominated Major $t_{-1} \times$ GPA Major Ratio ${ }_{t-1}$ & $\begin{array}{c}2.767 \\
(2.958)\end{array}$ \\
\hline Female-Dominated Major $_{t-1}$ & $\begin{array}{l}-3.427 \\
(2.095)\end{array}$ \\
\hline Female $\times$ Female-Dominated Major $_{t-1}$ & $\begin{array}{c}3.678 \\
(2.495)\end{array}$ \\
\hline Female-Dominated Major $_{t-1} \times$ GPA Major Ratio $t-1$ & $\begin{array}{l}4.895^{* * *} \\
(1.490)\end{array}$ \\
\hline Female $\times$ Female-Dominated Major $t_{-1} \times$ GPA Major Ratio ${ }_{t-1}$ & $\begin{array}{l}-3.413^{* *} \\
(1.672)\end{array}$ \\
\hline STEM Major $_{t-1}$ & $\begin{array}{l}-3.695^{* *} \\
(1.627)\end{array}$ \\
\hline Female $\times$ STEM Major $t-1$ & $\begin{array}{c}0.102 \\
(2.332)\end{array}$ \\
\hline STEM Major $_{t-1} \times$ GPA Major Ratio $_{t-1}$ & $\begin{array}{l}1.105 \\
(0.955)\end{array}$ \\
\hline STEM Major $_{t-1} \times$ Male-Dominated Major $_{t-1}$ & $\begin{array}{c}3.472 \\
(3.459)\end{array}$ \\
\hline STEM Major $_{t-1} \times$ Female-Dominated Major $_{t-1}$ & $\begin{array}{l}-2.913 \\
(4.361)\end{array}$ \\
\hline Female $\times$ STEM Major $t_{t-1} \times$ GPA Major Ratio $_{t-1}$ & $\begin{array}{l}1.449 \\
(1.293)\end{array}$ \\
\hline 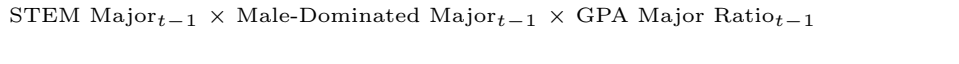 & $\begin{array}{l}-4.545 \\
(3.137)\end{array}$ \\
\hline 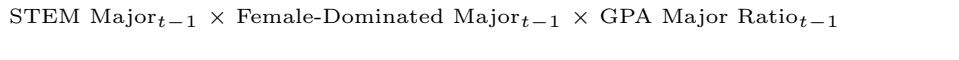 & $\begin{array}{l}-2.628 \\
(5.540)\end{array}$ \\
\hline Female $\times$ STEM Major $t-1 \times$ Male-Dominated Major $t-1$ & $\begin{array}{l}-4.422 \\
(4.685)\end{array}$ \\
\hline Female $\times$ STEM Major $t-1 \times$ Female-Dominated Major $_{t-1}$ & $\begin{array}{l}-2.620 \\
(6.674)\end{array}$ \\
\hline Female $\times$ STEM Major $_{t-1} \times$ Male-Dominated Major $t-1 \times$ GPA Major Ratio $_{t-1}$ & $\begin{array}{c}6.395 \\
(4.543)\end{array}$ \\
\hline Female $\times$ STEM Major $t-1 \times$ Female-Dominated Major $t_{t-1} \times$ GPA Major Ratio $t-1$ & $\begin{array}{c}4.304 \\
(5.921) \\
\end{array}$ \\
\hline Observations & 15,466 \\
\hline Pseudo $R^{2}$ & 0.29 \\
\hline
\end{tabular}




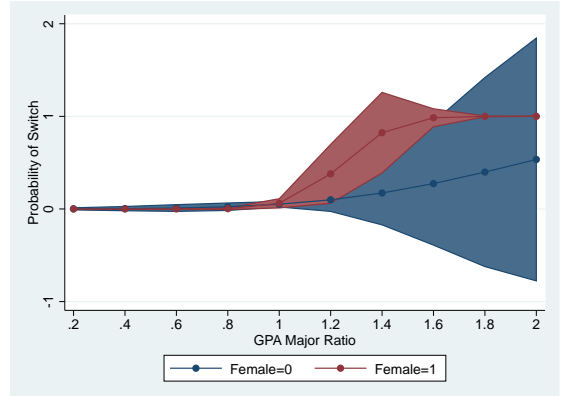

(a) Probability of Switch out of MD Major. Females

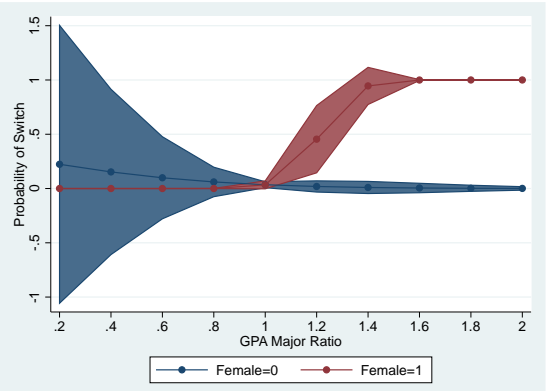

(c) Probability of Switch out of MD STEM. Females

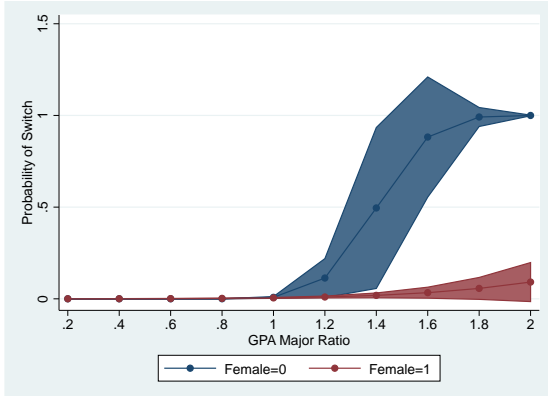

(b) Probability of Switch out of FD Major. Males

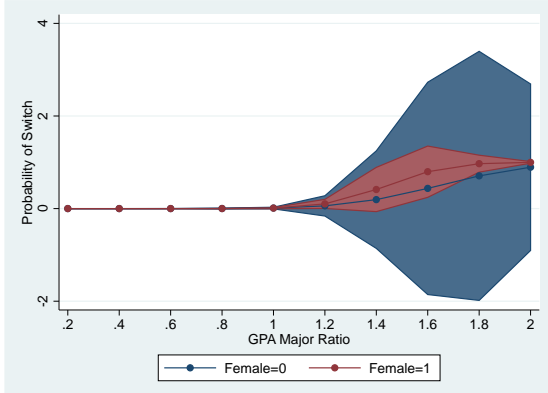

(d) Probability of Switch out of FD STEM. Males

Figure 1 


\section{References}

Altonji, J. G. (1995). The effects of high school curriculum on education and labor market outcomes. Journal of Human Resources 30(3), 409-38.

Arcidiacono, P. (2004). Ability sorting and the returns to college major. Journal of Econometrics 121(1), 343-375.

Arcidiacono, P., V. J. Hotz, and S. Kang (2012). Modeling college major choices using elicited measures of expectations and counterfactuals. Journal of Econometrics 166(1), $3-16$.

Astorne-Figari, C. and J. D. Speer (2017). Are changes of major, major changes? The roles of grades, gender, and preferences in college major switching. Working Paper.

Bettinger, E. P. and B. T. Long (2005). Do faculty serve as role models? the impact of instructor gender on female students. The American Economic Review 95(2), 152-157.

Blau, F. D. and L. M. Kahn (2006). The gender pay gap: Going, going... but not gone. The declining significance of gender, 37-66.

Blom, E., B. C. Cadena, and B. J. Keys (2015). Investment over the business cycle: Insights from college major choice.

Bradley, E. S. (2012). The effect of the business cycle on freshman major choice.

Bronson, M. A. (2014). Degrees are forever: Marriage, educational investment, and lifecycle labor decisions of men and women. Unpublished manuscript 2.

Campbell, S. M. and M. L. Collaer (2009). Stereotype threat and gender differences in performance on a novel visuospatial task. Psychology of Women Quarterly 33(4), 437444. 
Canes, B. J. and H. S. Rosen (1995). Following in her footsteps? faculty gender composition and women's choices of college majors. ILR Review 48(3), 486-504.

Carrell, S. E., M. E. Page, and J. E. West (2010). Sex and science: How professor gender perpetuates the gender gap. The Quarterly Journal of Economics 125(3), 1101-1144.

Chung, K.-S. (2000). Role models and arguments for affirmative action. The American Economic Review 90(3), 640-648.

Dynan, K. E. and C. E. Rouse (1997). The underrepresentation of women in economics: A study of undergraduate economics students. The Journal of Economic Education 28(4), $350-368$.

Feld, J. and U. Zölitz (2017). Understanding peer effects: on the nature, estimation, and channels of peer effects. Journal of Labor Economics 35(2), 387-428.

Francis, B., L. Archer, J. Moote, J. DeWitt, E. MacLeod, and L. Yeomans (2017). The construction of physics as a quintessentially masculine subject: Young people's perceptions of gender issues in access to physics. Sex Roles 76(3-4), 156-174.

Gemici, A. and M. Wiswall (2014). Evolution of gender differences in post-secondary human capital investments: College majors. International Economic Review 55(1), 23-56.

Goldin, C., L. F. Katz, and I. Kuziemko (2006). The homecoming of american college women: The reversal of the college gender gap. The Journal of Economic Perspectives 20(4), 133133.

Griffith, A. L. (2010). Persistence of women and minorities in stem field majors: Is it the school that matters? Economics of Education Review 29(6), 911-922.

Grogger, J. and E. Eide (1995). Changes in college skills and the rise in the college wage premium. Journal of Human Resources, 280-310. 
Hackett, G. (1985). Role of mathematics self-efficacy in the choice of math-related majors of college women and men: A path analysis. Journal of counseling psychology 32(1), 47.

Jensen, E. J. and A. L. Owen (2000). Why are women such reluctant economists? evidence from liberal arts colleges. The American Economic Review 90(2), 466-470.

Johnson, M. and V. S. Helgeson (2002). Sex differences in response to evaluative feedback: A field study. Psychology of Women Quarterly 26(3), 242-251.

Kirkeboen, L. J., E. Leuven, and M. Mogstad (2016). Field of study, earnings, and selfselection. The Quarterly Journal of Economics 131(3), 1057-1111.

Lavy, V. and E. Sand (2015). On the origins of gender human capital gaps: Short and long term consequences of teachers' stereotypical biases. Working Paper, National Bureau of Economic Research.

Levine, P. B. and D. J. Zimmerman (1995). The benefit of additional high-school math and science classes for young men and women. Journal of Business 83 Economic Statistics 13(2), 137-149.

Long, V. O. (1986). Relationship of masculinity to self-esteem and self-acceptance in female professionals, college students, clients, and victims of domestic violence. Journal of consulting and clinical psychology 54(3), 323.

Manski, C. F. (1993). Dynamic choice in social settings: Learning from the experiences of others. Journal of Econometrics 58(1-2), 121-136.

Mayo, M., M. Kakarika, J. C. Pastor, and S. Brutus (2012). Aligning or inflating your leadership self-image? a longitudinal study of responses to peer feedback in mba teams. Academy of Management Learning \& Education 11(4), 631-652.

Morgan, S. L., D. Gelbgiser, and K. A. Weeden (2013). Feeding the pipeline: Gender, occupational plans, and college major selection. Social Science Research 42(4), 989-1005. 
Ost, B. (2010). The role of peers and grades in determining major persistence in the sciences. Economics of Education Review 29(6), 923-934.

Oxoby, R. J. (2014). Social inference and occupational choice: Type-based beliefs in a bayesian model of class formation. Journal of Behavioral and Experimental Economics 51, $30-37$.

Roberts, T.-A. (1991). Gender and the influence of evaluations on self-assessments in achievement settings. Psychological bulletin 109(2), 297.

Speer, J. D. (2017). The gender gap in college major: Revisiting the role of pre-college factors. Labour Economics 44, 69-88.

Spencer, S. J., C. M. Steele, and D. M. Quinn (1999). Stereotype threat and women's math performance. Journal of experimental social psychology 35(1), 4-28.

Steele, C. M. and J. Aronson (1995). Stereotype threat and the intellectual test performance of african americans. Journal of personality and social psychology 69(5), 797.

Stinebrickner, R. and T. R. Stinebrickner (2013). A major in science? initial beliefs and final outcomes for college major and dropout. Review of Economic Studies 81(1), 426-472.

Turner, S. E. and W. G. Bowen (1999). Choice of major: The changing (unchanging) gender gap. ILR Review 52(2), 289-313.

Tversky, A. and D. Kahneman (1975). Judgment under uncertainty: Heuristics and biases. In Utility, probability, and human decision making, pp. 141-162. Springer.

Wiswall, M. and B. Zafar (2014). Determinants of college major choice: Identification using an information experiment. The Review of Economic Studies 82(2), 791-824.

Zafar, B. (2013). College major choice and the gender gap. Journal of Human Resources 48(3), 545-595. 
Table A1: Estimation Results. Switch. 2008-2016

\begin{tabular}{|c|c|c|c|}
\hline & $\begin{array}{c}(1) \\
\text { Switch } \\
\beta / \mathrm{SE}\end{array}$ & $\begin{array}{c}(2) \\
\text { Switch } \\
\beta / \mathrm{SE}\end{array}$ & $\begin{array}{c}(3) \\
\text { Switch } \\
\beta / \mathrm{SE}\end{array}$ \\
\hline Female & $\begin{array}{l}-0.005 \\
(0.027)\end{array}$ & $\begin{array}{c}0.316 \\
(1.588)\end{array}$ & $\begin{array}{l}-1.364 \\
(1.836)\end{array}$ \\
\hline Non-citizen & $\begin{array}{l}0.126^{* *} \\
(0.058)\end{array}$ & $\begin{array}{l}-0.003 \\
(0.111)\end{array}$ & $\begin{array}{l}-0.010 \\
(0.116)\end{array}$ \\
\hline Hispanic & $\begin{array}{c}0.041 \\
(0.052)\end{array}$ & $\begin{array}{c}0.060 \\
(0.096)\end{array}$ & $\begin{array}{c}0.030 \\
(0.098)\end{array}$ \\
\hline Black & $\begin{array}{c}0.089 \\
(0.057)\end{array}$ & $\begin{array}{l}0.181^{*} \\
(0.097)\end{array}$ & $\begin{array}{c}0.148 \\
(0.103)\end{array}$ \\
\hline Asian & $\begin{array}{l}0.035 \\
(0.041)\end{array}$ & $\begin{array}{l}-0.024 \\
(0.072)\end{array}$ & $\begin{array}{l}-0.018 \\
(0.073)\end{array}$ \\
\hline Other Minority & $\begin{array}{c}0.017 \\
(0.058)\end{array}$ & $\begin{array}{l}-0.114 \\
(0.111)\end{array}$ & $\begin{array}{l}-0.098 \\
(0.113)\end{array}$ \\
\hline Sophomore Year & $\begin{array}{l}0.896^{* * *} \\
(0.054)\end{array}$ & $\begin{array}{l}0.969^{* * *} \\
(0.138)\end{array}$ & $\begin{array}{l}1.031^{* * *} \\
(0.145)\end{array}$ \\
\hline Junior Year & $\begin{array}{l}0.678^{* * *} \\
(0.055)\end{array}$ & $\begin{array}{l}0.628^{* * *} \\
(0.138)\end{array}$ & $\begin{array}{l}0.668^{* * *} \\
(0.145)\end{array}$ \\
\hline Other School & $\begin{array}{l}-0.071 \\
(0.122)\end{array}$ & $\begin{array}{l}-0.068 \\
(0.239)\end{array}$ & $\begin{array}{l}-0.128 \\
(0.227)\end{array}$ \\
\hline Catholic School & $\begin{array}{c}0.006 \\
(0.033)\end{array}$ & $\begin{array}{c}0.040 \\
(0.059)\end{array}$ & $\begin{array}{c}0.027 \\
(0.060)\end{array}$ \\
\hline Independ. School & $\begin{array}{c}0.009 \\
(0.031)\end{array}$ & $\begin{array}{l}0.040 \\
(0.057)\end{array}$ & $\begin{array}{c}0.026 \\
(0.059)\end{array}$ \\
\hline Predeclared Major & $\begin{array}{l}0.965^{* * *} \\
(0.027)\end{array}$ & $\begin{array}{l}1.079^{* * *} \\
(0.065)\end{array}$ & $\begin{array}{l}1.279^{* * *} \\
(0.081)\end{array}$ \\
\hline ACT English & $\begin{array}{c}0.006 \\
(0.005)\end{array}$ & $\begin{array}{c}0.007 \\
(0.008)\end{array}$ & $\begin{array}{c}0.012 \\
(0.009)\end{array}$ \\
\hline ACT Math & $\begin{array}{l}-0.000 \\
(0.005)\end{array}$ & $\begin{array}{c}0.012 \\
(0.009)\end{array}$ & $\begin{array}{l}-0.000 \\
(0.010)\end{array}$ \\
\hline Low Fin. Need & $\begin{array}{l}-0.018 \\
(0.048)\end{array}$ & $\begin{array}{l}-0.039 \\
(0.084)\end{array}$ & $\begin{array}{l}-0.039 \\
(0.084)\end{array}$ \\
\hline Medium Fin. Need & $\begin{array}{c}0.033 \\
(0.036)\end{array}$ & $\begin{array}{c}0.076 \\
(0.063)\end{array}$ & $\begin{array}{l}0.118^{*} \\
(0.065)\end{array}$ \\
\hline High Fin. Need & $\begin{array}{c}0.053 \\
(0.035)\end{array}$ & $\begin{array}{l}0.141^{* *} \\
(0.063)\end{array}$ & $\begin{array}{l}0.166^{* *} \\
(0.067)\end{array}$ \\
\hline GPA Major Ratio $t-1$ & & $\begin{array}{l}1.488^{* * * *} \\
(0.440)\end{array}$ & $\begin{array}{l}1.186^{* *} \\
(0.490)\end{array}$ \\
\hline Classmates Females Ratio $t-1$ & & $\begin{array}{l}-0.105 \\
(0.276)\end{array}$ & $\begin{array}{l}0.283 \\
(0.205)\end{array}$ \\
\hline Classmates Non-Citizens Ratio $t-1$ & & $\begin{array}{l}-0.014 \\
(0.066)\end{array}$ & $\begin{array}{l}-0.022 \\
(0.075)\end{array}$ \\
\hline Classmates Black Ratio $t-1$ & & $\begin{array}{l}0.081 \\
(0.054)\end{array}$ & $\begin{array}{c}0.094 \\
(0.058)\end{array}$ \\
\hline Classmates Hispanic Ratio $t-1$ & & $\begin{array}{l}0.120^{* *} \\
(0.049)\end{array}$ & $\begin{array}{l}0.139^{* *} \\
(0.057)\end{array}$ \\
\hline Classmates Asian Ratio $t-1$ & & $\begin{array}{l}-0.002 \\
(0.092)\end{array}$ & $\begin{array}{l}-0.017 \\
(0.110)\end{array}$ \\
\hline Classmates Other Minority Ratio $t-1$ & & $\begin{array}{l}-0.014 \\
(0.054)\end{array}$ & $\begin{array}{l}-0.052 \\
(0.059)\end{array}$ \\
\hline Faculty Female Ratio $t-1$ & & $\begin{array}{l}0.053 \\
(0.069)\end{array}$ & $\begin{array}{c}0.039 \\
(0.076)\end{array}$ \\
\hline Faculty Non-White Ratio $t-1$ & & $\begin{array}{l}-0.030 \\
(0.029)\end{array}$ & $\begin{array}{l}-0.026 \\
(0.030)\end{array}$ \\
\hline Faculty Non-Citizens Ratio $_{t-1}$ & & $\begin{array}{l}-0.050 \\
(0.032)\end{array}$ & $\begin{array}{l}-0.052 \\
(0.034)\end{array}$ \\
\hline Median Wage Ratio $t-1$ & & $\begin{array}{l}-0.925^{* *} \\
(0.426)\end{array}$ & $\begin{array}{l}-0.730 \\
(0.475)\end{array}$ \\
\hline Employment Rate Ratio ${ }_{t-1}$ & & $\begin{array}{l}2.119^{* *} \\
(1.035)\end{array}$ & $\begin{array}{l}2.315^{* *} \\
(1.173)\end{array}$ \\
\hline Part Time Jobs Ratio $t-1$ & & $\begin{array}{l}-0.266 \\
(0.214)\end{array}$ & $\begin{array}{l}-0.229 \\
(0.246)\end{array}$ \\
\hline Female $\times$ GPA Major Ratio $t-1$ & & $\begin{array}{l}-0.590 \\
(0.493)\end{array}$ & $\begin{array}{l}-0.492 \\
(0.592)\end{array}$ \\
\hline Female $\times$ Classmates Females Ratio $t-1$ & & $\begin{array}{l}-0.027 \\
(0.456)\end{array}$ & $\begin{array}{c}0.102 \\
(0.356)\end{array}$ \\
\hline Female $\times$ Faculty Female Ratio $t-1$ & & $\begin{array}{l}-0.148 \\
(0.099)\end{array}$ & $\begin{array}{l}-0.134 \\
(0.101)\end{array}$ \\
\hline Female $\times$ Median Wage Ratio $t-1$ & & $\begin{array}{l}-0.180 \\
(0.570)\end{array}$ & $\begin{array}{c}0.815 \\
(0.590)\end{array}$ \\
\hline Female $\times$ Employment Rate Ratio $t-1$ & & $\begin{array}{c}0.228 \\
(1.127)\end{array}$ & $\begin{array}{c}0.851 \\
(1.331)\end{array}$ \\
\hline Female $\times$ Part Time Jobs Ratio $t-1$ & & $\begin{array}{c}0.310 \\
(0.269)\end{array}$ & $\begin{array}{c}0.322 \\
(0.329)\end{array}$ \\
\hline Male-Dominated Major $_{t-1}$ & & & $\begin{array}{c}0.366 \\
(1.845)\end{array}$ \\
\hline Female $\times$ Male-Dominated Major $t-1$ & & & $\begin{array}{l}-4.961^{*} \\
(2.893)\end{array}$ \\
\hline Male-Dominated Major $_{t-1} \times$ GPA Major Ratio $_{t-1}$ & & & $\begin{array}{r}-0.259 \\
(1.660)\end{array}$ \\
\hline Male-Dominated Major $t-1 \times$ Classmates Females Ratio ${ }_{t-1}$ & & & $\begin{array}{l}-1.663^{*} \\
(0.875)\end{array}$ \\
\hline Male-Dominated Major ${ }_{t-1} \times$ Median Wage Ratio $_{t-1}$ & & & $\begin{array}{l}2.287^{* * *} \\
(0.641)\end{array}$ \\
\hline
\end{tabular}




\begin{tabular}{|c|c|c|c|}
\hline & (1) & (2) & (3) \\
\hline Female $\times$ Male-Dominated Major $t-1 \times$ GPA Major Ratio $t-1$ & & & $\begin{array}{l}6.044^{* *} \\
(2.831)\end{array}$ \\
\hline Female $\times$ Male-Dominated Major $t_{-1} \times$ Classmates Females Ratio $t_{-1}$ & & & $\begin{array}{l}-0.865 \\
(1.416)\end{array}$ \\
\hline Female $\times$ Male-Dominated Major $t-1 \times$ Median Wage Ratio $t-1$ & & & $\begin{array}{l}-0.203 \\
(1.065)\end{array}$ \\
\hline Female-Dominated Major ${ }_{t-1}$ & & & $\begin{array}{l}-4.780^{*} \\
(2.728)\end{array}$ \\
\hline Female $\times$ Female-Dominated Major $_{t-1}$ & & & $\begin{array}{l}9.850^{* * *} \\
(3.272)\end{array}$ \\
\hline Female-Dominated Major ${ }_{t-1} \times$ GPA Major Ratio $_{t-1}$ & & & $\begin{array}{l}4.826^{* * *} \\
(1.500)\end{array}$ \\
\hline 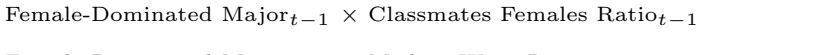 & & & $\begin{array}{c}0.507 \\
(1.325)\end{array}$ \\
\hline Female-Dominated Major $t-1 \times$ Median Wage Ratio $_{t-1}$ & & & $\begin{array}{l}-0.666 \\
(1.321)\end{array}$ \\
\hline Female $\times$ Female-Dominated Major $_{t-1} \times$ GPA Major Ratio $t-1$ & & & $\begin{array}{l}-4.807^{* * *} \\
(1.565)\end{array}$ \\
\hline Female $\times$ Female-Dominated Major $_{t-1} \times$ Classmates Females Ratio $t-1$ & & & $\begin{array}{l}-2.242 \\
(1.785)\end{array}$ \\
\hline Female $\times$ Female-Dominated Major $_{t-1} \times$ Median Wage Ratio $t-1$ & & & $\begin{array}{l}-3.101^{*} \\
(1.718)\end{array}$ \\
\hline 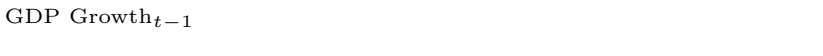 & $\begin{array}{l}2.901^{* * *} \\
(0.665)\end{array}$ & $\begin{array}{l}128.647^{* * *} \\
(48.013)\end{array}$ & $\begin{array}{l}128.230^{* * *} \\
(49.553)\end{array}$ \\
\hline GDP Growth $_{t-1} \times$ Median Wage Ratio $_{t-1}$ & & $\begin{array}{c}0.796 \\
(15.744)\end{array}$ & $\begin{array}{l}11.665 \\
(16.247)\end{array}$ \\
\hline GDP Growth $_{t-1} \times$ Employment Rate Ratio $_{t-1}$ & & $\begin{array}{l}-118.959 * * * \\
(41.640)\end{array}$ & $\begin{array}{l}-134.766^{* * *} \\
(43.778)\end{array}$ \\
\hline GDP Growth $_{t-1} \times$ Part Time Jobs Ratio $_{t-1}$ & & $\begin{array}{l}-6.505 \\
(8.389)\end{array}$ & $\begin{array}{l}-1.476 \\
(8.675)\end{array}$ \\
\hline Constant & $\begin{array}{l}-3.266^{* * *} \\
(0.174)\end{array}$ & $\begin{array}{l}-6.462^{* * *} \\
(1.377)\end{array}$ & $\begin{array}{l}-6.901^{* * *} \\
(1.540)\end{array}$ \\
\hline Observations & 42,934 & 15,466 & 15,466 \\
\hline Pseudo $R^{2}$ & 0.15 & 0.19 & 0.22 \\
\hline
\end{tabular}

Note: $\star$ Significant at 10 percent; $\star \star$ Significant at 5 percent; $\star \star \star$ Significant at 1 percent. Standard errors in parentheses. Need band, school type dummies, and constant are not reported. 
Table A2: Estimation Results. Switch. 2008-2016

\begin{tabular}{|c|c|}
\hline & $\begin{array}{c}(1) \\
\text { Switch } \\
\beta / \mathrm{SE}\end{array}$ \\
\hline Female & $\begin{array}{l}0.969 \\
(2.167)\end{array}$ \\
\hline Non-citizen & $\begin{array}{l}-0.002 \\
(0.124)\end{array}$ \\
\hline Hispanic & $\begin{array}{c}0.021 \\
(0.104)\end{array}$ \\
\hline Black & $\begin{array}{c}0.096 \\
(0.109)\end{array}$ \\
\hline Asian & $\begin{array}{c}0.011 \\
(0.077)\end{array}$ \\
\hline Other Minority & $\begin{array}{l}-0.068 \\
(0.117)\end{array}$ \\
\hline Sophomore Year & $\begin{array}{l}1.102^{* * *} \\
(0.156)\end{array}$ \\
\hline Junior Year & $\begin{array}{l}0.540^{* * *} \\
(0.156)\end{array}$ \\
\hline Other School & $\begin{array}{c}0.023 \\
(0.244)\end{array}$ \\
\hline Catholic School & $\begin{array}{l}-0.017 \\
(0.064)\end{array}$ \\
\hline Independ. School & $\begin{array}{c}0.074 \\
(0.064)\end{array}$ \\
\hline Predeclared Major & $\begin{array}{l}0.616^{* * *} \\
(0.122)\end{array}$ \\
\hline ACT English & $\begin{array}{c}0.014 \\
(0.009)\end{array}$ \\
\hline ACT Math & $\begin{array}{l}-0.023^{* *} \\
(0.011)\end{array}$ \\
\hline Low Fin. Need & $\begin{array}{l}-0.032 \\
(0.089)\end{array}$ \\
\hline Medium Fin. Need & $\begin{array}{l}0.111 \\
(0.071)\end{array}$ \\
\hline High Fin. Need & $\begin{array}{l}0.183^{* * *} \\
(0.070)\end{array}$ \\
\hline GPA Major Ratio $t-1$ & $\begin{array}{l}0.469 \\
(0.557)\end{array}$ \\
\hline Classmates Females Ratio $t-1$ & $\begin{array}{c}0.187 \\
(0.270)\end{array}$ \\
\hline Classmates Non-Citizens Ratio $_{t-1}$ & $\begin{array}{l}-0.053 \\
(0.084)\end{array}$ \\
\hline Classmates Black Ratio $t-1$ & $\begin{array}{c}0.045 \\
(0.072)\end{array}$ \\
\hline Classmates Hispanic Ratio ${ }_{t-1}$ & $\begin{array}{c}0.090 \\
(0.065)\end{array}$ \\
\hline Classmates Asian Ratio $t-1$ & $\begin{array}{c}0.040 \\
(0.117)\end{array}$ \\
\hline Classmates Other Minority Ratio ${ }_{t-1}$ & $\begin{array}{l}-0.082 \\
(0.075)\end{array}$ \\
\hline Faculty Female Ratio $t-1$ & $\begin{array}{l}-0.047 \\
(0.087)\end{array}$ \\
\hline Faculty Non-White Ratio $t-1$ & $\begin{array}{l}-0.024 \\
(0.047)\end{array}$ \\
\hline Faculty Non-Citizens Ratio $t-1$ & $\begin{array}{l}-0.067 \\
(0.051)\end{array}$ \\
\hline Median Wage Ratio $t-1$ & $\begin{array}{l}-0.931 \\
(0.707)\end{array}$ \\
\hline Employment Rate Ratio $t-1$ & $\begin{array}{l}0.901 \\
(1.397)\end{array}$ \\
\hline Part Time Jobs Ratio $t-1$ & $\begin{array}{l}-0.246 \\
(0.262)\end{array}$ \\
\hline Female $\times$ GPA Major Ratio $t-1$ & $\begin{array}{l}-1.245 \\
(0.912)\end{array}$ \\
\hline Female $\times$ Classmates Females Ratio $t-1$ & $\begin{array}{c}0.135 \\
(0.575)\end{array}$ \\
\hline Female $\times$ Faculty Female Ratio $t-1$ & $\begin{array}{l}-0.076 \\
(0.129)\end{array}$ \\
\hline Female $\times$ Median Wage Ratio ${ }_{t-1}$ & $\begin{array}{l}-0.166 \\
(0.950)\end{array}$ \\
\hline Female $\times$ Employment Rate Ratio $t-1$ & $\begin{array}{c}0.376 \\
(1.491)\end{array}$ \\
\hline Female $\times$ Part Time Jobs Ratio $t-1$ & $\begin{array}{c}0.122 \\
(0.373)\end{array}$ \\
\hline Male-Dominated Major $_{t-1}$ & $\begin{array}{c}2.481 \\
(1.944)\end{array}$ \\
\hline Female $\times$ Male-Dominated Major $t-1$ & $\begin{array}{l}-3.531 \\
(3.227)\end{array}$ \\
\hline Male-Dominated Major $_{t-1} \times$ GPA Major Ratio $_{t-1}$ & $\begin{array}{l}1.444 \\
(1.556)\end{array}$ \\
\hline Male-Dominated Major ${ }_{t-1} \times$ Classmates Females Ratio $_{t-1}$ & $\begin{array}{l}-2.491^{* *} \\
(1.158)\end{array}$ \\
\hline Female $\times$ Male-Dominated Major $t_{-1} \times$ GPA Major Ratio $_{t-1}$ & $\begin{array}{c}2.767 \\
(2.958)\end{array}$ \\
\hline Female $\times$ Male-Dominated Major $t-1 \times$ Classmates Females Ratio $t-1$ & $\begin{array}{c}0.612 \\
(1.582)\end{array}$ \\
\hline Female-Dominated Major ${ }_{t-1}$ & $\begin{array}{l}-3.427 \\
(2.095)\end{array}$ \\
\hline
\end{tabular}




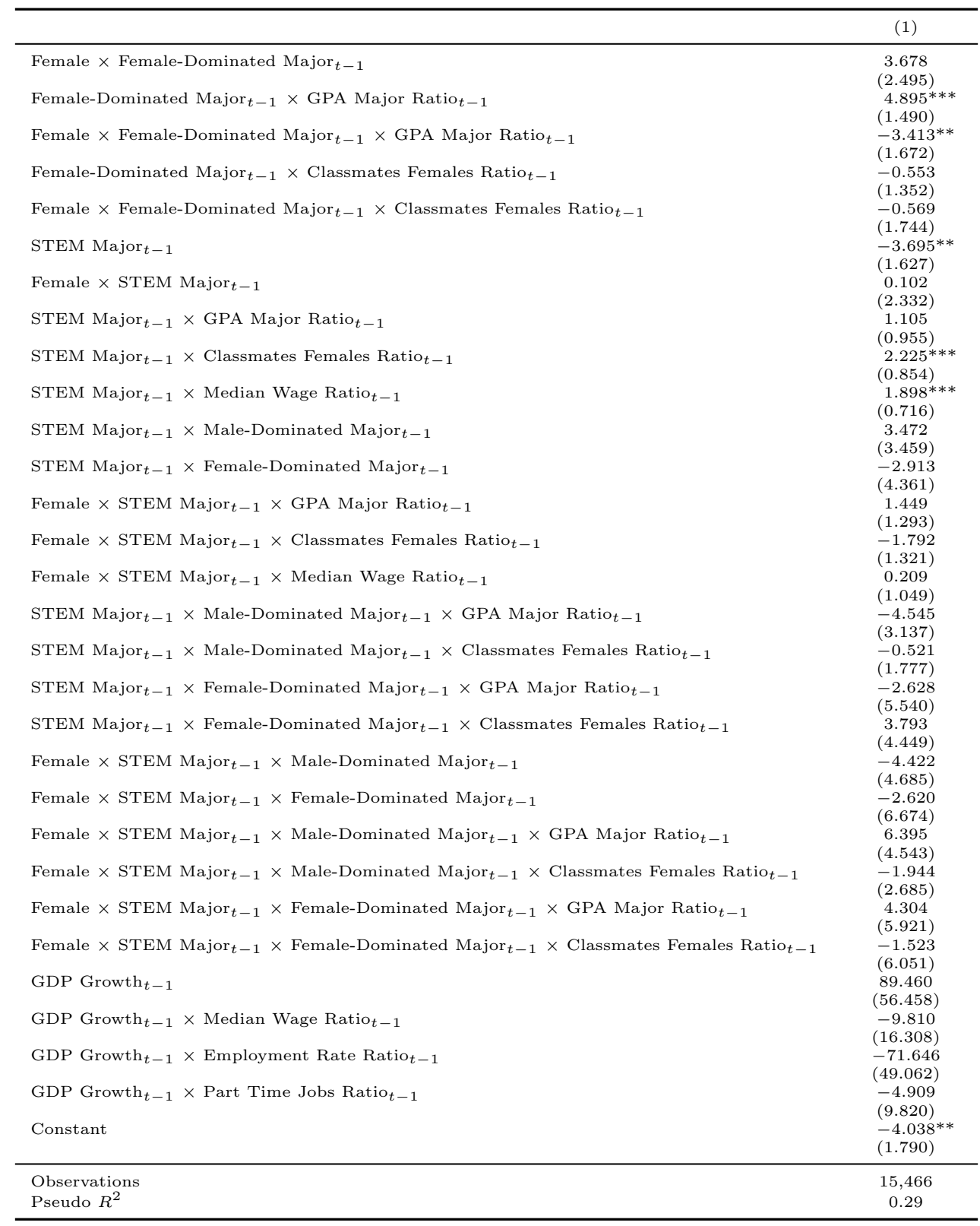

Note: $\star$ Significant at 10 percent; $\star \star$ Significant at 5 percent; $\star \star \star$ Significant at 1 percent. Standard errors in parentheses. Need band, school type dummies, and constant are not reported. 